\title{
A Test of Narrow Framing and its Origin
}

\section{Luigi Guiso}

Received: 28 June 2014 / Accepted: 20 November 2014 / Published online: 19 February 2015 (C) Società Italiana degli Economisti (Italian Economic Association) 2015

\begin{abstract}
I provide a test of narrow framing to explain why individuals turn down small positive expected value lotteries. Participants in a large survey have been asked whether they would accept a small lottery of winning 180 euros with probability of $1 / 2$ or losing 100 euros with the same probability. Half of the sample, randomly selected, answered the lottery question immediately after they were asked to think about and report their subjective probability distribution of future earnings; the other half made the decision before. Consistent with narrow framing, I find that individuals that were induced to bring their earnings risk to mind before facing the decision are significantly less likely to turn it down. Furthemore, only those who actually say they are uncertain about their incomes are less likely to reject the lottery. I show that attitudes towards regret and reliance on intuition rather than reasoning are likely to drive the tendency to frame choices narrowly.
\end{abstract}

Keywords Narrow framing · Loss aversion - Intuitive thinking · Reasoning · Regret

JEL Classification D1 D 8

\section{Introduction}

It has been argued recently that "narrow framing" — a tendency of people to evaluate a risky prospect in isolation rather than mixing it with the other risks they face-may

I thank seminar articipants at Bocconi University, University of Bologna, Columbia University, EIEF and Georgetown University for helpful comments. I am greateful to Nick Barberis, Ray Chetty, James Choi and Jesse Shapiro for useful comments and discussion. I am greatful to the editor and the referee for the useful comments provided. I thank Unicredit for making the survey data available and for financial support.

L. Guiso $(\varangle)$

Einaudi Institute for Economics and Finance (EIEF), Rome, Italy

e-mail: luigi.guiso@eief.it 
be much more important in explaining decisions than has been thought so far. For instance, Barberis et al. (2006) argue that narrow framing can explain why individuals turn down small, independent gambles with a positive expected return. This, not only is at odds with standard expected utility preferences (Rabin 2000), but would be hard to reconcile even with preferences characterized by loss aversion when, realistically, individuals face other risks as well. The reason why this is so is that, as Kahneman (2003) observes, narrowly framed decisions depart far more from risk neutrality than those that are made in a more inclusive context. In fact, by focusing only on the one specific prospect, one ignores the risk-diversification properties that the prospect may have when considered together with other risks, making the specific prospect less appealing. In other words, narrow framing inhibits one from taking advantage of diversification opportunities, which by definition require joint evaluation of risky prospects. As shown by Barberis and Huang (2006), narrow framing is a critical ingredient for the behavioral approach to the equity premium puzzle; and Barberis et al. (2006) show that narrow framing can help explain one important puzzle in finance - the fact that contrary to the standard portfolio model a substantial fraction of individuals do not invest in stocks (Mankiw and Zeldes 1991; Haliassos and Bertaut 1995). Furthermore, Brown et al. (2008) show that narrow framing can in principle explain a long-time old consumption puzzle: the under-annuitization puzzle. That is the fact that very few consumers annuitize their retirement savings contrary to the prediction of standard consumption models that most should. Brown et al. (2008) also provide experimental evidence that narrow framing actually explains the puzzle. ${ }^{1}$

While the potential consequences of narrow framing are starting to be better understood and models that incorporate narrow framing into tractable preference specifications are beginning to appear (Barberis and Huang 2006), empirical tests of narrow framing and even more so of its origin are still lacking. In this paper I provide a test of narrow framing in a large sample of individual investors interviewed in 2007 and offer some evidence of what can lead individuals to frame choices narrowly, drawing on a few recent theories. The strategy of the test is simple and relies on the idea that the prevalence of narrowly framed decisions is an effect of "accessibility" (Kahneman 2003) - that is, of the ease with which mentally recorded information that may be relevant to the assessment of a risky prospect is recalled (Higgins 1996).

My strategy consists in facing individuals with a decision concerning a small investment (or lottery) with positive expected value while randomly changing the degree of accessibility. To achieve this, sample participants were asked to think about and report the probability distribution of their future earnings. This provides information about the human capital risk they face, which they would probably find it desirable to hedge. Half of the individuals in the sample, randomly chosen, were asked to make the choice concerning the small investment before the questions about labor income expectations were asked. The other half, instead, made the decision immediately after the probability distribution of their future earnings was elicited. Hence, when deciding about the small investment, individuals in the second group have a greater accessibility to their human capital risk so their decision should be less subject to narrow framing. In

1 see Kahneman (2011). 
fact, since the small investment is by construction independent of the human capital risk, it should provide diversification against the latter. Individuals with readier access should recognize this benefit and thus be less likely to turn down the investment.

I find that in both groups, most individuals reject the small lottery, in concordance with a substantial body of experimental evidence (Kahneman and Tversky 1979; Tversky and Kahneman 1981, 1992). However, individuals that have easier access to their human capital risk are significantly less likely to do so: the difference in the rejection rate between the two groups is more than $8 \%$, or about $13 \%$ of the sample rejection rate. This result is invariant to adding controls for individual demographic characteristics and attitudes such as risk aversion.

In our sample, not all individuals face income uncertainty, at least over the one year horizon for which they are asked to give their earnings probability distribution. Since the diversification benefits of the small independent lottery are greater for those who actually face income uncertainty, one should find that those with earnings risk are less likely to turn down the lottery, if they decide under partial narrow framing. In fact, I find that those who face uncertain incomes are less likely to refuse. However, income uncertainty has no effect for those who were asked to decide about the lottery before reporting their human capital risk while it is negative and significant for those who have decided after their labor income risk was elicited. This result is consistent with the first group framing the decision about the lottery narrowly because when deciding they fail to bring to mind the other risks they face. The second group, instead, thanks to readier accessibility of income uncertainty, can at least partially take advantage of the diversification possibilities offered by the lottery.

One important issue is what features of decision-making trigger narrowly framed choices. Kahneman (2003) argues that narrowly framed decisions are a consequence of individuals' relying on intuitive thinking rather than reasoning (on the two cognitive processes see Stanovich and West 2000, 2002). Since intuitive thinking is immediate and highly dependent on the specific elements available (Stanovich and West 2000, 2002; Hammond 1996), individuals who rely on intuition will depend more on the most accessible elements. Hence, according to this view, an intuitive thinker will focus mostly on the specific features of the lottery and tend to assess its value in isolation from other risks whose relation to the lottery is not immediately accessible. On the contrary, individuals that rely on reasoning will be more receptive to less accessible information and be more likely to become aware of the diversification benefits offered by the small lottery. Thus their decision should be more responsive to accessibility.

It has also been argued (Barberis and Huang 2006) that narrow framing could reflect regret at possibly having made a poor choice compared to a better alternative (Roese and Olson 1995). Since regret comes from comparing the consequences of a specific action with those of a verifiable alternative it leads people to focus on the outcomes of the action itself and ignore their contribution to overall wealth. Hence, regret-prone individuals should be more likely to frame the small lottery narrowly and turn it down.

The UCS survey collects information on whether individuals rely mostly on intuitive thinking or on systematic reasoning when making decisions as well as on their propensity to regret. When I control for regret I find that regret-prone individuals are more likely to reject the lottery. When I sort the sample according to thinking mode, I find that the probability of turning the lottery down is lowest for those who rely mostly 
on reasoning and for whom the probability distribution of their future earnings is more readily accessible. For those who rely on reasoning, access to their income risk lowers the probability of turning the lottery down by as much as $12 \%$ points, about $20 \%$ of the sample rejection rate. By contrast, making their human capital risk more accessible to individuals who rely on intuition has no perceptible effect on the decision. This evidence is consistent with narrow framing being triggered by the decision mode and amplified by regret.

Several papers report evidence that is consistent with the existence of narrow framing in experimental settings, starting with Tversky and Kahneman (1981), who show that individuals when offered to choose between two pairs of concurrent risky prospects decide by comparing single pairs, not the combined outcome of the decisions, and end up choosing a dominated combination. Read et al. (1999) survey this literature and provide various examples from different domains that are suggestive of narrow framing, including Sabini and Silver (1982), Camerer et al. (1995), Thaler et al. (1997), Thaler (2000). None of these papers, however, uses narrow framing to explain why people turn down small lotteries when they face other pre-existing risks. Most importantly, this contribution differs from previous ones because I use predictions from emerging theories to inquire into the cause of narrow framing, thus strengthening the interpretation.

Most recently, Rabin and Weizsacker (2009) in a remarkable study revisit and extend (Tversky and Kahneman 1981) example and show that the tendency to choose dominated lotteries when offered a set of concurrent risky prospects is much more general than one may be led to conclude on the basis of Tversky and Kahneman (1981) and other similar examples. In what is probably the closest paper to this one, they show both in an experimental setting and using a large representative survey, that a majority of people choose dominated strategies when prospects are presented in isolation. But this disappears when the joint distribution of these prospects is shown, consistent with narrow framing driving their decisions. Importantly, they also prove theoretically that even small degrees of narrow framing can result in people making dominated choices, provided preferences depart from CARA, a definitely mild requirement (e.g., Guiso and Paiella 2008). Like Rabin and Weizsacker (2009) we find evidence of narrow framing but in a different context, that of a small lottery and pre-existing risk. Unlike them we also test for the source of narrow framing by studying the role of two potentially important drivers: regret and thinking mode. Hence, the two studies should be viewed as complementing each other.

This paper is also related to a recent strand of literature in economics that inquires into the determinants of departures from the predictions of standard expected utility models. In particular the work of Frederick (2005), Benjamin et al. (2006), Kirby et al. (2005), Dohmen et al. (2011), who focus on the role of cognitive ability in explaining aversion to small, beneficial risks and high discounting. Differently from these papers we focus on narrow framing and the role played by the individual's prevalent decision process.

At a more general level, the evidence I find that narrow framing can be traced back to individuals thinking mode is related to a new strand of literature both empirical (e.g., McClure et al. 2004; Sirigu et al. 2004; Breiter et al. 2001; Butler et al. 2013) and theoretical (e.g., Fudenberg and Levine 2006; Brocas and Carrillo 2008a, b) maintaining that fundamental preference parameters usually taken as given can be traced 
back to the architecture of the brain and the interplay between emotion (or intuition) and reasoning.

The rest of the paper is organized as follows. Section 2 sets up a simple framework to illustrate how narrow framing can explain why people turn down small lotteries and show the role of thinking mode, regret and other factors. Section 3 describes the data and the test design. Section 4 presents the main results and Sect. 5 provides evidence on the role of theory-based determinants of narrow framing. Section 6 concludes.

\section{Framework}

To illustrate our test strategy and obtain testable implications I set up a simple framework. Let $\widetilde{x}$ be a small lottery granting a gain $g$ with probability $1 / 2$ and a loss $-l$ with the the same probability. Individuals are loss-averse; losses and gains are evaluated by a piecewise linear utility function with reference point at 0 . The expected utility of this lottery if evaluated in isolation is $E v(\widetilde{x})=(1 / 2) g-\lambda(1 / 2) l$, where $\lambda$ denotes the individual's degree of loss aversion. Thus, if $g / l<\lambda$ individuals reject this lottery. For instance, suppose $g=180$ euros and $l=100$ euros; most individuals should reject this lottery since, as shown by Tversky and Kahneman (1991), Tversky and Kahneman (1992) for the median individual the degree of loss aversion is around 2 or slightly larger. Hence, the expected utility from entering the lottery $E v(\widetilde{x})=(1 / 2) g-\lambda(1 / 2) l=(1 / 2)(180-2 \times 100)=-10$ which is lower than the utility from not taking it. Thus, loss aversion easily explains why the majority of individuals (though not all) reject small positive-value risks when evaluated in isolation. This was the explanation put forward by Rabin and Thaler (2001), with an emphasis on loss aversion. However, in a recent article Barberis et al. (2006) notice that in the definitely more realistic case where individuals face some pre-existing risk-notably labor income risk-it should be hard for them to reject a small independent lottery even if they are loss-averse. In fact, the lottery offers some risk diversification of the pre-existing risk, making it hard to reject it at non-unreasonable levels of loss aversion. Of course, in order to reap the diversification benefit that the small lottery offers, the individual must evaluate it by mixing the lottery $\widetilde{x}$ with the pre-existing risk, and evaluate what the lottery contributes to the distribution of overall wealth rather than the utility of the lottery itself.

To solve the puzzle constituted by the fact that people do indeed reject small independent lotteries, Barberis et al. (2006) assume that utility is also affected by the lottery directly in addition to its effect when mixed with pre-existing risks. The extent of this direct effect depends on how narrowly people evaluate $\tilde{x}$, that is on how exposed to narrow framing they are.

Following Barberis et al. (2001, 2006) and Barberis and Huang (2006), a preference specification that allows for variable degrees of narrow framing is:

$$
V_{t}=U\left(C_{t}, \mu\left(\widetilde{V}_{t+1} / I_{t}\right)+b E v\left(\widetilde{x}_{t+1}\right)\right)
$$

where $C_{t}$ denotes current period consumption, $\mu\left(\widetilde{V}_{t+1} / I_{t}\right)$ is the certainty equivalent of future utility conditional on the information, $I_{t}$, available at $t$, and $v\left(\widetilde{x}_{t+1}\right)$ is the direct utility that the consumer obtains from assessing the prospect $\widetilde{x}_{t+1}$ in isolation. 
The function $v\left(\widetilde{x}_{t+1}\right)$ is characterized by loss aversion-say, $v(x)=x$ if $x>0$ and $v(x)=\lambda x$ if $x<0$, with $\lambda>1$. Uncertainty about $\tilde{x}_{t+1}$ will be resolved between time $t$ and $t+1$ when uncertainty about some pre-existing risk is resolved; thus, since $\tilde{x}_{t+1}$ is independent of the other risks, it can offer risk diversification. In this specification the individual receives utility from the lottery in two ways: because the lottery offers diversification when merged with a pre-existing risk and also directly. This direct effect is captured by the term $b v\left(\widetilde{x}_{t+1}\right)$. The parameter $b$ measures how important this second channel is and can be thought of as an index of narrow framing. Individuals who decide about the lottery narrowly will be characterized by a large value of $b$. Absence of narrow framing obtains when $b$ is equal to zero. In this case the decision about the small lottery is taken on the basis of its contribution to final wealth, that is by comparing $V_{t}=U\left(C_{t}, \mu\left(\widetilde{V}_{t+1}\right)\right)$ when the lottery $\tilde{x}_{t+1}$ is accepted with its value when is not accepted. A central result of Barberis et al. (2006) (see their Proposition 1 ) is that the lottery is generally accepted even if the $U($ ) is characterized by first loss aversion as in Gul (1991), provided individuals face some pre-existing risk. In fact, people will not turn down the small lottery $\tilde{x}$, because it allows to diversify the pre-existing risk. The term $b v\left(\widetilde{x}_{t+1}\right)$ is meant to reconcile the preference specification with the fact that people actually do turn down small lotteries with positive expected value. As shown above $E v(\widetilde{x})$ is normally negative for values of the degree of loss aversion exceeding 2 . Thus, allowing for narrow framing balances the diversification benefit of the lottery and can even reverse it, leading to its rejection if the degree of narrow framing is sufficiently large (see Barberis et al. 2006). ${ }^{2}$

This formalizes Kahneman and Lovallo (1993) idea that narrow framing, by limiting the recognition of the benefits from pooling risks, leads to too overcautious decisions.

\subsection{Narrow Framing Theory}

But what drives the degree of narrow framing? This is critical for devising more powerful tests of the plausibility of this approach in explaining why individuals are so reluctant to take on small favorable gambles. Since $b$ is unobservable, understanding its origin can suggest how to identify a source of variation in the degree of narrow framing, which can then be used to test the empirical validity of this approach. Barberis et al. (2006) acknowledge that their approach "...does not prove that narrow framing is at work in the case of monetary gambles".., but only that..."given the difficulties faced by standard preferences,.. the narrow framing view may need to be taken more

\footnotetext{
2 An example helps. Suppose initial uncertain income (in deviation from the reference point) is given by the prospect $[40,000,-10,000 ; 1 / 2,1 / 2]$. Consider the small lottery $[180,-100 ; 1 / 2,1 / 2]$ which is turned down if $\lambda>1.8$ if assessed in isolation. Suppose $\lambda=2$ for a consumer who therefore rejects the small lottery when assessed in isolation. If she mixes the lottery with the pre-existing risk she contrasts the utility $\frac{1}{2}(40,000-2 \times 10,000)=10,000$ if the lottery were turned down with the utility $\frac{1}{4} 40,180+\frac{1}{4} 39,900-$ $\frac{1}{4} 2 \times 9,820-\frac{1}{4} 2 \times 10,100=10,060$ if the lottery were accepted. Hence, when mixed with he pre-existing risk the lottery is not turned down. Interestingly, the diversification benefit may still be substantial even if the pre-existing risk is small (so that the small lottery risk is relatively large). For instance, if the pre-existing risk is $[200,-50 ; 1 / 2,1 / 2]$ the small risk is still accepted when mixing as utility from accepting is 55 and only 50 from turning it down.
} 
seriously..” (p. 1085). How seriously depends on its ability to address the puzzle empirically.

One explanation put forward by Kahneman (2003) in his Nobel lecture is that narrow framing occurs when decisions are made intuitively rather than through systematic reasoning. Following current research in psychology, he distinguishes two modes of thinking and making decisions. The first relies on effortful reasoning and systematic processing of information. By its very nature, this mode of thinking is analytic, controlled by the decision maker, relatively slow and less affected by the context. People that use this mode of thinking are less likely to frame decisions narrowly. In fact, effortful reasoning helps bring to mind all the potentially relevant elements many of which would be difficult to retrieve in the particular circumstances where the decision is made unless one put effort into the thinking process. For instance, in the context of the small lottery $\tilde{x}$ with effortful reasoning one will be more likely to be aware of the other risks he faces and how they may interact with the lottery and thus be more likely to realize the diversification benefits that $\widetilde{x}$ offers. Such a person would be less exposed to narrow framing and carry a lower $b$. "Dual process theory" (e.g., Sloman 1996; Hammond 1996), posits intuitive thinking as the other decision-making process. While reasoning is deliberate, intuitive thinking is by and large automatic, and intuitive decisions are driven by spontaneous reactions to the elements that first come to mind. Thus, intuitive decisions tend to be associative (that is, driven by inference based on prior experiences in similar circumstances) and most importantly to be strongly affected by the elements of the context in which the decision is made. These elements dominate the mind of the decision maker, while other factors that may be relevant to the problem at hand are not retrieved. This implies that the elements that come to mind most easily in the particular context of the decision being made_-e.g., because they are more visible-are likely to carry more weight.

In Kahneman's language, when making intuitive decisions the relevant elements are the ones that are most "accessible". For the choice of a small lottery $\tilde{x}$ an intuitive thinker may have easier access to the features of the lottery itself, such as its losses and gains, and thus tend to focus on them when deciding about the lottery, ignoring potentially relevant interactions with other components of his wealth. The latter may be left in the background or be ignored altogether in deciding whether to accept or reject $\tilde{x}$.

In other words, intuitive thoughts are more likely to give access only to the most visible attributes of the objects of choice (Kahneman 2003). Intuitive thinkers can be characterized as having a high value of $b$, while people who rely on reasoning, will tend to de-contextualize problems and abstract from the particular circumstances, and be characterized by a lower value of $b$.

In terms of the above preference representation, let $b$ depend on accessibility, denoted by $a$, and reasoning, denoted by $r$. Let $a$ be an index that takes values between 0 and 1 of the ease with which the relevant elements of the decision are accessible. Accessibility will depend on how these elements are represented, the context where the decision is made, etc. A value of 0 implies that these elements are impossible to visualize and thus to use in a decision, as, for instance, when information is made available in an unknown language, or the context where the decision is made is such 
that it is very hard to bring to mind some relevant elements even through effortful reasoning. A value of 1 implies instead that all the elements are readily accessible. Thinking mode can also be thought of as a continuous variable that varies between 0 and 1 with 0 denoting pure intuitive thinking and 1 pure reasoning. A simple relationship that captures the dependence of the degree of narrow framing from accessibility and thinking mode is

$$
b=b_{0}(1-a r)
$$

This formalization has several interesting properties. First, for given $r$, dependence on narrow framing declines as accessibility increases. Second, more intuition-intense decisions-lower $r$-imply, ceteris paribus, more narrow framing. Third, the decline in narrow framing as accessibility increases, $\frac{\partial b}{\partial a}=-r$, is more pronounced when individuals base decisions more on reasoning than on intuition. This captures the idea that intuition-based decisions are less capable of benefiting from increased accessibility. The important point is that if one can induce variation in the degree of accessibility and possibly observe the way people make decisions, one can obtain variation in the degree of narrow framing and thus be able to assess its empirical relevance. This is the test strategy I follow in this paper. ${ }^{3}$

Before illustrating how I devise the test, it is worth mentioning that there could be other sources of narrow framing besides accessibility and modes of thinking. ${ }^{4}$ For instance, Barberis and Huang (2006) argue that narrow framing may reflect nonconsumption utility, such as regret. Regret is commonly defined as the nagging feeling of having made the wrong choice, shunning a better alternative (Roese and Olson 1995). It is a prominent form of counterfactual thinking, the comparison between "what might have been" and "what actually was". Since regret is typically linked to the comparison of the consequences of a specific action-like the gain or loss when accepting a lottery - with those of a verifiable alternative (such as not taking the lottery) regret naturally induces a focus on the outcomes of the action itself and neglect of the contribution of its consequences to overall wealth; but this is what narrow framing is about.

\footnotetext{
3 This way of modelling the link between narrow framing and accessibility implies also that narrow framing is lower for those who rely on reasoning. Thus, ceteris paribus, one should find that people who rely on reasoning are less likely to turn down a small lottery. This implication, which is in principle testable, however is true if thinking mode only affects the decision about the small lottery through its effect on framing. However, Butler et al. (2014) show that thinking mode is also correlated with risk preferences: those who rely on reasoning tend to be more risk averse than intuitive thinkers. Thus they should tend to reject the lottery more often-the opposite implication of what the narrow framing channel implies. In other words, the effect of thinking mode on the lottery acceptance is ambiguous. There is no ambiguity instead in the effect of accessibility, which is by construction uncorrelated with the risk attitudes of people in our sample and can only affect the lottery decision because of it affects framing.

4 Redelmeier and Tversky (1992) and Read et al. (1999) argue that decision frames adopted by individuals are affected by the way the various alternatives are presented. namely, whether decisions are presented to them one at time or simultaneously affects how they frame them. The concept of accessibility contains this possibility. When decisions are presented simultaneously their aggreate effects are more accessible than when they are presented sequentially and distant from each other. Out test strategy can be seen as one that manipulates the extent of the separation between the decision and other elements that are relevant to it.
} 
In our context, regret entails a larger value of $b$. To allow for this let

$$
b=b_{0}(1-a r)+z
$$

where $z$ is a vector of other determinants of the degree of narrow framing, such as regret.

\section{Test Design and Data}

\subsection{Data}

The central idea of the test is to expose different groups of individuals who are asked to decide about a small lottery with positive expected payoff to different degrees of accessibility to the income risk that they face. For this I have relied on the second wave of the Unicredit Clients' Survey (UCS) which between June and September 2007 interviewed a sample of 1,686 Italian customers of Unicredit, one of the largest European banking groups. The sample was stratified according to three criteria: geographical area, city size and financial wealth. To be included, clients needed to have at least 10,000 euros of assets with Unicredit; the survey explicitly over-sampled wealthy clients. The survey is described in greater detail in the data appendix.

\subsection{Test Design}

The test strategy consists of three steps. First, following Guiso et al. (2002), survey participants were asked about the probability distribution of earnings one year ahead. More specifically, they were asked:

Assuming that you will be working over the next 12 months, can you tell me:

(a) The minimum amount $\left(y_{m}\right)$ that over the 12 months you expect to earn, net of taxes but including items like overtime, bonuses, etc.

(b) The maximum amount ( $\left.y_{M}\right)$ that over the 12 months you expect to earn, net of taxes but including items like overtime, bonuses, etc.

Can you now tell me the probability that you would assign to your income being greater than the value $X=\left(y_{m}+y_{M}\right) / 2$ (the interviewer reads the value that appears on the monitor). That is if you were to assign a score between 0 and 100 to the event "your income over the next 12 months will be greater than X", what score would you assign?

Under certain assumptions about the shape of the distribution above and below the midpoint, this information allows for an estimate of different moments of the distribution of future earnings, including measures of uncertainty. The simplest, which requires no distributional assumptions and which I will be using later on is the range $y_{M}-y_{m}$ which is positive if the individual faces some income uncertainty. This question was asked towards the middle part of the interview after several other sections covering information on demographics, education, attitudes and propensity to save and invest, financial information and banking relations, financial portfolios. 
Second, respondents were asked whether they would be willing to accept a small lottery in which with probability $1 / 2$ you either win 180 euros or lose 100 euros. The exact wording of the proposed lottery is:

Suppose that over the next 12 months a small investment of 100 euros allows you to gain 180 euros with a probability $1 / 2$ and to lose the 100 euros with probability $1 / 2$. In either case you will know about the outcome of the investment (i.e. whether you will get 180 euros or you will have to pay 100 euros) 12 months from now. Whether you win or lose is decided upon tossing a coin (you choose whether tails or head). Would you agree to participate in this investment?

Individuals can answer by saying "yes", "no" or "I do not know". The expected value of the lottery is 40 euros and, under the assumption of linearity in the assessment of losses and gains, a loss-averse person with a loss-aversion parameter of 1.8 who evaluates the lottery in isolation would be indifferent between rejecting and accepting. I have chosen the 180 euros gain/100 euros loss lottery since loss aversion of 1.8 is just below the typical estimate of 2-2.25 that seems to characterize the median respondent in experimental settings (Tversky and Kahneman 1991, 1992).

Three features of this question are worth noticing. First, the lottery is presented as a small investment. This is done intentionally to minimize the possibility that people will reject it because they are, perhaps morally, averse to gambling. Second, to make sure that the lottery can provide diversification, its outcome is based on the toss of a coin, so that it is by construction independent from the respondent's pre-existing risks. Third, the uncertainty about the lottery is resolved over a 12-month horizon, that is, over the same time span individuals face their human capital uncertainty elicited in the previous question. This feature is important because as stressed by Barberis et al. (2006) the diversification value of the lottery for some preference representations may depend on whether the resolution of the lottery uncertainty is "immediate" or whether it is "delayed", as only the latter may provide diversification against the earnings risk that is resolved in the future.

The third step is to induce random variation in the accessibility of pre-existing risks and thus implicitly in the degree of narrow framing. To do this, I randomize the location of the small lottery question in the questionnaire.

To half of the individuals interviewed, randomly chosen, the lottery question is asked before the distribution of their future earnings is elicited. To make sure that for this group mental access to preexisting risks is as limited as possible, the lottery question is asked in the second section of the questionnaire where questions about attitudes are asked, following the first section devoted to obtaining information about demographic characteristics such as gender, year of birth, family composition, education etc. In these sections no mention is made of earnings or income, either current or future, or of respondent's assets that may be subject to uncertainty. To the second group, instead, the lottery question is asked immediately after they answer the questions about their future earnings. Hence, since this group has greater access to the probability distribution of future earnings it should be easier for them to realize the potential diversification benefits that the lottery may provide. Thus, if narrow framing plays a role in the rejection of small, positive-return lotteries, the rejection rate should be higher in the 
first than in the second group. The second group, in fact, has a higher value of $a$ and, according to equation (2), less narrow framing.

This is the logic of the test strategy and its main testable implication.

\subsection{Variation in Narrow Framing: Modes of Thinking and Regret}

To sharpen the test of narrow framing, I have also sought to learn how individuals typically approach decisions and their sensitivity to regret. To obtain an indication of the mode of thinking, respondents were asked to answer the following question:

Think now about when you make a decision. Generally speaking do you tend to decide rather quickly, relying mostly on your intuition, or rather do you tend to think carefully about all possible alternatives and consequences of your choice, taking as much time as needed before reaching a final decision?

Respondents can answer in one of three ways: (1) "I decide very rapidly on the basis of my intuition"; (2) "I partly ponder and partly rely on intuition"; (3) "I ponder carefully, reasoning deeply on my choice". The answers to this question partition the sample in three groups that differ in the relevance of intuitive thinking in their decisions. The fraction of intuitive thinkers is $14.6 \%$; the rest is divided equally between those who rely on both and those use mostly reasoning (Table 1, panel D).

For this indicator to be a valid measure of thinking mode, two conditions must hold. First, since it is based on self-reported information, one must be sure that people are actually aware of how they approach decisions. One way to check this assumption is to notice that UCS participants were asked how they approach a decision to make a purchase that involves a substantial amount of money, such as buying a durable. The exact wording of the questions is: "Before making a purchase involving a relatively large amount of money (such as a car, a washing machine or furniture), some people tend to visit several shops or dealers in order to compare various prices and try to get a good balance in terms of price/quality ratio. How does this description fits your type?"5 One would expect the description to fit people who rely on reasoning better. And in fact the "purchase mode" variable is highly correlated with the thinking mode indicator. People who rely more on reasoning tend to visit more shops and make more comparisons than those who rely on intuition. The correlation coefficient between the two variables is 0.21 and a regression of thinking mode on "purchase mode" results in a highly statistically significant coefficient ( $t$-stat 8.67$){ }^{6}$

Second, since I rely on differences between individuals in how they make decisions, the underlying assumption is that even though all people obviously use both modes of thinking, intuitive thinking is more prevalent in some than in others. That is, reliance on intuition versus reasoning must be to some extent an individual trait. Stanovich and West (2000) provide evidence for this assumption. They argue that the systematic

\footnotetext{
5 The possible answers are "Not at all", "Very little, "Somewhat", "Close enough", "Very much". We code these answers attaching numbers between 1 and 5 .

6 In Sect. 5.2 I discuss in detail how thinking mode is related to cognitive ability and show that it is not a proxy for the latter.
} 
Table 1 Descriptive statistics

\begin{tabular}{|c|c|c|c|}
\hline A. Small lottery and accessibility & $\begin{array}{l}(1) \\
\text { Mean }\end{array}$ & $\begin{array}{l}(2) \\
\text { Median }\end{array}$ & $\begin{array}{l}(3) \\
\text { Standard } \\
\text { deviation }\end{array}$ \\
\hline Fraction turning down the lottery: total sample & 0.608 & 1 & 0.488 \\
\hline $\begin{array}{l}\text { Fraction turning down the lottery: } \\
\text { dropping the "I do not know" answers }\end{array}$ & 0.685 & 1 & 0.465 \\
\hline Accessibility to pre-existing risks & 0.53 & 1 & 0.50 \\
\hline
\end{tabular}

B. Demographics, income and wealth

(1)

(2)

(3)

Variable

Mean

Median

Standard deviation

\begin{tabular}{|c|c|c|c|}
\hline Age & 54.81 & 57 & 12.27 \\
\hline Fraction male & 0.70 & 1 & 0.46 \\
\hline Education (no. of years) & 12.73 & 13 & 4.25 \\
\hline Fraction married & 0.68 & 1 & 0.46 \\
\hline Resident in the North & 0.51 & 1 & 0.50 \\
\hline Resident in the center & 0.24 & 0 & 0.43 \\
\hline City size indicator & 4.52 & 5 & 1.17 \\
\hline Financial wealth (thousand euros) & 208.60 & 120 & 408.01 \\
\hline Income (thousand euros) & 50.17 & 31 & 67.84 \\
\hline Face earnings uncertainty (whole sample) & 0.40 & 0 & 0.49 \\
\hline $\begin{array}{l}\text { Face earnings uncertainty (among those } \\
\text { in the labor force) }\end{array}$ & 0.67 & 1 & 0.47 \\
\hline C. Attitudes & (1) & (2) & (3) \\
\hline Variable & Mean & Median & $\begin{array}{l}\text { Standard } \\
\text { deviation }\end{array}$ \\
\hline Low risk aversion & 0.28 & 0 & 0.45 \\
\hline Medium risk aversion & 0.53 & 1 & 0.50 \\
\hline High risk aversion & 0.19 & 0 & 0.39 \\
\hline Risk aversion: quantitative (euros) & $4,210.50$ & 4,000 & $3,333.60$ \\
\hline Generalized trust & 0.26 & 0 & 0.44 \\
\hline Subjective discount & 3.58 & 4 & 1.78 \\
\hline D. Regret, intuition and reasoning & (1) & (2) & (3) \\
\hline Variable & Mean & Median & $\begin{array}{l}\text { Standard } \\
\text { deviation }\end{array}$ \\
\hline Regret losses & 2.20 & 2 & 0.74 \\
\hline No regret & 0.21 & 0 & 0.41 \\
\hline Some regret & 0.42 & 0 & 0.49 \\
\hline Regret a lot & 0.38 & 0 & 0.48 \\
\hline
\end{tabular}


Table 1 continued

\begin{tabular}{lccc}
\hline D. Regret, intuition and reasoning & $(1)$ & $(2)$ & $(3)$ \\
Variable & Mean & Median & $\begin{array}{c}\text { Standard } \\
\text { deviation }\end{array}$ \\
\hline Regret gains & & 2.67 & 0.63 \\
$\quad$ No regret & 0.42 & 0 & 0.49 \\
$\quad$ Some regret & 0.49 & 0 & 0.50 \\
$\quad$ Regret a lot & 0.09 & 0 & 0.29 \\
Rely mostly on intuition & 0.15 & 1 & 0.35 \\
Rely both on intuition and reasoning & 0.43 & 1 & 0.49 \\
Rely mostly on reasoning & 0.42 & 1 & 0.49 \\
\hline E. Interview controls & Mean & Median & Standard \\
& & & deviation \\
\hline Length of interview (minutes) & 62.27 & 60 & 20.22 \\
Understanding of questions & 7.60 & 8 & 1.90 \\
Easiness in answering questions & 7.40 & 8 & 1.95 \\
Overall interview climate & 8.12 & 8 & 1.85 \\
\hline
\end{tabular}

This table shows summary statistic for the variables that are used in the estimates. Panel $A$ shows summary statistics for the fraction that rejecting a small lottery $\left[180-100 ; \frac{1}{2}, \frac{1}{2}\right]$ and an indicator of accessibility to pre-existing risks. Accessibility is an indicator equal to 1 if the individual has answered the small lottery question after elicitation of the probability distribution of income one year-ahead; zero if he answered at the beginning of the questionnaire. Panel $B$ contains summary statistics about demographics, income and wealth. Education is the number of years of schooling an college. Financial wealth is the value of financial assets held with Unicredit from administrative record, in thousands of euros. Income is in thousand of euros. Panel $C$ shows summary statistics for risk attitudes, generalized trust and subjective discount. Low risk aversion is a dummy $=1$ if the individual prefers a relatively high return together with a relatively high risk (zero otherwise) when making portfolio decisions; Medium risk aversion is a dummy $=1$ if he prefers a satisfactory return with some moderate risk; High risk aversion is a dummy $=1$ if he prefers a very low return with no risk (zero otherwise). The quantitative risk aversion indicator is the value in euros makes the individual indifferent between accepting that money for sure and a lottery here he wins 10,000 euros with probability $\frac{1}{2}$ and 0 with probability $\frac{1}{2}$. Generalized trust is a dummy equal to one if the individual thinks that most people can be trusted. Subjective discount is a categorical variable between 1 and 6 with 1 corresponding to low discount (between 0 and $2 \%$ ) and 6 corresponding to high discount ( $20 \%$ or more). In Panel D regret losses in an indicator variable between 1 and 3 with one corresponding to no regret when an avoidable loss is incurred, 2 some regret and 3 regret a lot. Regret missed gains is similarly defined. "Rely on intuition" is a dummy equal to 1 if people say they mostly rely on intuition when making decisions;" Rely both on intuition and reasoning" and "Rely mostly on reasoning" are similarly defined. In Panel E length of interview is minutes the interview lasted; the remaining three variables are qualitative indicators with scores between 1 and 10 reported by the interviewer at the end of the interview. Understanding is meant to measure how well questions were understood, easiness how difficult was to answer them and climate a general measure of how well the interview was received

differences in performance for a large variety of tasks observed in a sample of individuals can be traced to the prevalence of one system of thinking or the other. Similarly, Klein (2003) offers numerous examples consistent with the idea that individuals differ systematically in their propensity to rely on intuition. In addition, evidence from twins studies points to a strong genetic component in the way people make decisions, suggesting that decision mode is indeed a stable trait (Bouchard and Hur 1998). 
Finally, to obtain an indicator of regret, individuals were asked to answer the following pair of questions, focusing respectively on losses incurred losses and gains forgone.

Could you please tell me how you would react if you found yourself in the following situation? Two years ago a friend who is knowledgeable about finance recommended that you undertake an investment which, on the basis of the information available to him then, had good chances of success.

(A) You chose not to make the investment. Meanwhile, the value of the investment has more than doubled and had you made it you could have made a big gain. In such circumstances, today you would:

- Deeply regret for not having made the investment;

- Regret but not be too upset;

- Feel no regret.

(B) Now think of another situation. You invested a significant amount in the investment that was recommended. Meanwhile market conditions have deteriorated and your investment has lost half of its value. In such a circumstances, today you would:

- Deeply regret for not having made the investment;

- Regret but not be too upset;

- Feel no regret.

I have coded the variable regret for losses as 1 if no regret is felt, 2 if some regret and 3 for deep regret. Regret for forgone gains is coded similarly. The vast majority of individuals regret losses either deeply (37.6\%) or to some extent (41.8\%); the remaining $20.6 \%$ would feel no regret. Regret forgone gains is less intense as only $9 \%$ report deep regret, while $42 \%$ show no regret at all (Table 1, panel D). Yet, the two measures of regret are positively correlated (correlation coefficient 0.37 ).

These variables can be used to test some of the implications of narrow framing theories directly.

\subsection{Additional Variables: Risk Aversion, Trust and Time Discount}

Besides the variables illustrated above - the core of our test - the survey obtains some detailed financial and demographic variables. Here demographic variables refer to respondents to the small lottery and income expectations questions.

Several parts of the questionnaire cover individuals' attitudes, on such matters as risk, time discount and general trust. Since variation in acceptance of the small lottery may reflect such attitudes, these questions can prove to be important controls.

Risk aversion is measured by a qualitative indicator of risk tolerance patterned after the Survey of Consumer Finance: "Which of the following statements comes closest to the amount of financial risk that you are willing to take when you make your financial investment: (1) a very high return, with a very high risk of losing the money; (2) high return and high risk; (3) moderate return and moderate risk; or (4) low return and no risk." I construct four dummies ranking individuals from very low to very high risk aversion. Only $18.6 \%$ choose "low return and no risk", so most are 
willing to accept some risk if compensated by a higher return, but very few $(1.8 \%)$ are prepared to take very high risk and very high return (Table 1, panel C). Recent literature on eliciting preferences from survey data shows that qualitative questions on risk aversion are informative and have predictive power (See, among others, Barsky et al. 1997; Guiso and Paiella 2008; Dohmen et al. 2011). ${ }^{7}$ As a robustness check we have used a second indicator based on a number of choices that survey participants were given between a risky prospect that pays 10,000 euros or zero with probability $1 / 2$ and a sequence of nine certain payments of money of increasing size ranging from 100 euros to 9,000 euros. Under the assumption that preferences are exponential, an interval for the degree of absolute risk aversion is identified for each individual when the respondent switches from the safe to the risky prospect. ${ }^{8}$

A measure of trust is obtained by asking people the generalized trust question from the World Values Survey: "Generally speaking, would you say that most people can be trusted or that you can't be too careful in dealing with people?". They answer in one of two ways, "Most people can be trusted" or "Can't be too careful"; I have coded responses 1 for the first answer, and zero for the second. About $25 \%$ participants are generally trusting (Table 1, panel C).

Finally, to obtain a measure of time discount, participants were asked to choose between 100,000 euros one year ahead and $M$ immediately where $M<100,000$. The initial value of $M$ is set at 95,000 euros; if the respondent accepts the immediate sum he is then asked whether he would be willing to accept 90,000 euros now (if he rejects then he is asked about 97,000 euros); if he accepts 90,000 euros (turns down 97,000 euros) he is then asked whether he would accept 80,000 euros now $(98,000$ euros). If he turns down 80,000 euros his discount rate is above $20 \%$; if he turns down 98,000 euros the alternative is to wait one year and get 100,000 euros. I classify individuals into six categories with increasing subjective discount, where the smallest discount is between 0 and $2 \%$ and the largest is at least $20 \%$. Individuals seem quite impatient, with about $60 \%$ with a discount rate of at least $10 \%$; but $24 \%$ are patient with discount rates below $2 \%$. The data appendix reports the exact wording of the question and describes how the index is computed in greater detail.

Table 1 shows summary statistics for the variables used in the paper.

\section{Results}

\subsection{The Basic Test}

The test is based on random differences in UCS participant's access to information about their pre-existing risk. Out of a total of 1,689 survey participants $799(47.4 \%)$ where asked the small lottery question before that about their human capital risk; it was put to the remaining 877 (52.6\%) immediately after the income risk question.

\footnotetext{
7 To avoid answers to risk aversion being affected by background risk, questions about risk attitudes were asked to both groups before they answered their income uncertainty question.

8 The two indicators of risk aversion are positively correlated; a regression of the qualitative measure carries a $t$-stat of 4.67. Neither distinguishes between relative and absolute risk aversion. But since we can control for wealth, we can allow the risk-aversion indicator to reflect differences in risk preferences that don't arise from differences in endowments.
} 
Table 2 Moments of demographic characteristics for high and low accessibility survey participants

\begin{tabular}{lllcc}
\hline Variable & $\begin{array}{l}\text { (1) } \\
\text { Low accessibility } \\
\text { to pre-existing risk }\end{array}$ & $\begin{array}{l}\text { (2) } \\
\text { High accessibility } \\
\text { to pre-existing risk }\end{array}$ & $\begin{array}{l}\text { Difference } \\
\text { in means }\end{array}$ & $\begin{array}{l}\text { (4) } \\
p \text { value }\end{array}$ \\
\hline Age & $54.297(12.375)$ & $55.282(12.154)$ & 0.985 & 0.100 \\
Fraction male & $0.698(0.459)$ & $0.700(0.458)$ & 0.002 & 0.938 \\
Educations (no. of years) & $12.720(4.100)$ & $12.742(4.388)$ & 0.022 & 0.915 \\
Fraction married & $0.698(0.459)$ & $0.672(0.470)$ & -0.026 & 0.244 \\
Resident in the North & $0.503(0.500)$ & $0.522(0500)$ & 0.019 & 0.440 \\
Resident in the center & $0.252(0.434)$ & $0.234(0.424)$ & -0.017 & 0.415 \\
City size indicator & $4.543(0.197)$ & $4.506(1.151)$ & -0.037 & 0.518 \\
Financial wealth & $194.646(1.468)$ & $221.223(474.434)$ & 26.576 & 0.182 \\
Income & $51.537(73.991)$ & $49.978(61.826)$ & -1.559 & 0.638 \\
Number of observations & 799 & 887 & & \\
\hline
\end{tabular}

This table shows means and standard deviation (in brackets) of various characteristics for the total sample and for survey participants with low and high accessibility to pre-existing risk. High accessibility refers to individuals that have answered the small lottery question after elicitation of the probability distribution of income one year-ahead; low accessibility if answered at the beginning of the questionnaire. Column (3) shows the difference in means between the two groups and column (4) the $p$ value for the null that the means are equal in the two samples

Since interviews were computer-assisted, randomization was induced directly by the computer, which randomly assigned one of the two locations to the lottery question at start of interview. The somewhat different size of the two groups from the theoretical equal split, is due to two factors. First, some interviewers received a list with an odd number of contacts, automatically giving rise to some imbalance; second, and most importantly, because some interviews were not completed and drop-outs are more likely at the beginning than towards the end of the interview, which tends to inflate the observations in the second group. Nonetheless, the characteristics of the respondents do not seem to differ in any systematic way. Table 2 compares the two groups for five demographic characteristics (age, gender, education, whether married, dummies for residence in the North and the Center, and financial assets). The two groups seem to be very similar, as one would expect if individuals were randomly allocated. For all variables the difference in means is very small (column 3) and, with one exception, none differs significantly from zero at usual significance levels (last column). The exception is age, which differs between the two groups at the $10 \%$ level of significance. However, even for this variable the difference in means is small (1 year, 54.29 in the first group and 55.28 in the second); furthermore, the second moment of the distributions is also very similar in the two groups. This leads me to conclude that accessibility to other risks is quite randomly allocated among the respondents.

In the overall sample the vast majority (61\%), turn the small lottery down; 28 per cent accept it. Excluding the "don't knows" (11\%, Table 3, first column) the rejection rate rises to $68 \%$. These figures are fully consistent with those obtained in experiments (e.g., Tversky and Kahneman 1992) where it is found that the majority of participants reject small lotteries of the sort offered in the UCS survey. The rejection 
Table 3 The basic test. Rejection rates of the small lottery for high and low accessibility to pre-existing risk

\begin{tabular}{llllll}
\hline Variable & $(1)$ & $(2)$ & $(3)$ & $(4)$ & $(5)$ \\
& Total sample & $\begin{array}{l}\text { Low accessibility } \\
\text { to pre-existing risk }\end{array}$ & $\begin{array}{l}\text { High accessibility } \\
\text { to pre-existing risk }\end{array}$ & $\begin{array}{l}\text { Difference between } \\
\text { high and low } \\
\text { accessibility groups }\end{array}$ \\
\hline $\begin{array}{l}\text { Including the } \\
\text { "I do not know" } \\
\text { responses } \\
\text { (obs. 1,686) }\end{array}$ & $0.608(0.488)$ & $0.652(0.477)$ & $0.568(0.496)$ & -0.084 & 0.000 \\
$\begin{array}{l}\text { Dropping the } \\
\text { "I do not know" } \\
\text { responses } \\
\text { (obs. 1,496) }\end{array}$ & $0.685(0.465)$ & $0.725(0.447)$ & $0.649(0.478)$ & -0.076 & 0.002 \\
$\begin{array}{l}\text { Fraction of } \\
\text { "I do not know" } \\
\text { responses }\end{array}$ & 0.113 & 0.101 & & & 0.221 \\
\hline
\end{tabular}

The table shows mean rejection rates of the small lottery for different groups of respondents (columns 1, 2 and 3 ) and tests of the difference in mean rejection rates between high and low accessibility individuals. High accessibility identifies the respondents who have been asked the small lottery question after they report the distribution of their future income; low accessibility identifies respondents that answered the lottery question before the future income question. Column 5 reports the $p$ value for the null hypothesis that the rejection rate is the same in the high and low accessibility groups (or that the fraction answering "I do not know" is the same, last column)

rate is higher in the group with lower accessibility (second column) than in the group with greater accessibility (third column). Depending on whether the "don't knows" are included, the rejection rate among those with low accessibility to their endowment uncertainty is 65.2 or $72.5 \%$. In the high-accessibility group it is about $8 \%$ points lower, no matter how the control group is defined (column 4). This difference is highly statistically significant ( $p$ values $\leq 0.002$, last column) lending support to the idea that narrow framing does indeed affect the high propensity for rejection of these small advantageous lotteries. The result suggests that when other risks that the individual is facing are made more accessible to him, he comes to realize the benefits of mixing the small lottery with these risks, mitigating narrow framing and inducing what appear as less timid decisions (Kahneman and Lovallo 1993). However, since among this group too a large fraction still turn the lottery down the result seems also to imply that even bringing these risks to an individual's mind, while helping, is not enough to eliminate narrow framing of specific risks.

\subsection{Controlled Regressions}

Table 4 digs deeper into the test by showing controlled regressions. In the first panel the left-hand side is equal to 1 if the lottery was turned down and 0 otherwise; that is, "don't knows" are included in the control group. The first column reproduces the result in Table 3. The second column adds a number of demographic controls such as age, 
Table 4 Accessibility to pre-existing risks and rejection of a small beneficial lottery

\begin{tabular}{|c|c|c|c|c|}
\hline & $\begin{array}{l}\text { (1) } \\
\text { No controls }\end{array}$ & $\begin{array}{l}\text { (2) } \\
\text { Demographics }\end{array}$ & $\begin{array}{l}\text { (3) } \\
\text { Demographics } \\
\text { and attitudes }\end{array}$ & $\begin{array}{l}\text { (4) } \\
\text { Demographics } \\
\text { and attitudes }\end{array}$ \\
\hline \multicolumn{5}{|c|}{ Panel A. The control groups includes the "I do not know" } \\
\hline Accessibility & $\begin{array}{l}-0.084^{* * *} \\
(0.000)\end{array}$ & $\begin{array}{l}-0.090^{* * *} \\
(0.000)\end{array}$ & $\begin{array}{l}-0.089^{* * *} \\
(0.000)\end{array}$ & $\begin{array}{l}-0.090 * * * \\
(0.000)\end{array}$ \\
\hline Age & & $\begin{array}{l}0.003 * * * \\
(0.004)\end{array}$ & $\begin{array}{l}0.003 * * \\
(0.013)\end{array}$ & $\begin{array}{l}0.003 * * \\
(0.012)\end{array}$ \\
\hline Male & & $\begin{array}{l}-0.037 \\
(0.180)\end{array}$ & $\begin{array}{l}-0.024 \\
(0.379)\end{array}$ & $\begin{array}{l}-0.026 \\
(0.354)\end{array}$ \\
\hline Education & & $\begin{array}{l}-0.004 \\
(0.237)\end{array}$ & $\begin{array}{l}-0.002 \\
(0.531)\end{array}$ & $\begin{array}{l}-0.001 \\
(0.682)\end{array}$ \\
\hline Married & & $\begin{array}{l}0.061 * * \\
(0.024)\end{array}$ & $\begin{array}{l}0.064 * * \\
(0.018)\end{array}$ & $\begin{array}{l}0.064 * * \\
(0.019)\end{array}$ \\
\hline North & & $\begin{array}{l}-0.036 \\
(0.232)\end{array}$ & $\begin{array}{l}-0.033 \\
(0.271)\end{array}$ & $\begin{array}{l}-0.025 \\
(0.408)\end{array}$ \\
\hline Centre & & $\begin{array}{l}-0.053 \\
(0.126)\end{array}$ & $\begin{array}{l}-0.053 \\
(0.130)\end{array}$ & $\begin{array}{l}-0.041 \\
(0.244)\end{array}$ \\
\hline City size & & $\begin{array}{l}-0.044 * * * \\
(0.000)\end{array}$ & $\begin{array}{l}-0.046^{* * * *} \\
(0.000)\end{array}$ & $\begin{array}{l}-0.046^{* * * *} \\
(0.000)\end{array}$ \\
\hline Financial wealth & & $\begin{array}{l}0.018 \\
(0.782)\end{array}$ & $\begin{array}{l}0.037 \\
(0.563)\end{array}$ & $\begin{array}{l}0.020 \\
(0.754)\end{array}$ \\
\hline$(\text { Financial wealth })^{2}$ & & $\begin{array}{l}0.001 \\
(0.950)\end{array}$ & $\begin{array}{l}-0.002 \\
(0.875)\end{array}$ & $\begin{array}{l}-0.000 \\
(0.991)\end{array}$ \\
\hline Income & & $\begin{array}{l}-0.351 \\
(0.378)\end{array}$ & $\begin{array}{l}-0.225 \\
(0.575)\end{array}$ & $\begin{array}{l}-0.151 \\
(0.708)\end{array}$ \\
\hline$(\text { Income })^{2}$ & & $\begin{array}{l}0.232 \\
(0.756)\end{array}$ & $\begin{array}{l}0.030 \\
(0.968)\end{array}$ & $\begin{array}{l}-0.076 \\
(0.921)\end{array}$ \\
\hline Medium risk aversion & & & $\begin{array}{l}0.048 * \\
(0.086)\end{array}$ & $\begin{array}{l}0.047 * \\
(0.091)\end{array}$ \\
\hline High risk aversion & & & $\begin{array}{l}0.144 * * * \\
(0.000)\end{array}$ & $\begin{array}{l}0.144 * * * \\
(0.000)\end{array}$ \\
\hline Generalized trust & & & & $\begin{array}{l}-0.100 * * * \\
(0.000)\end{array}$ \\
\hline Subjective discount & & & & $\begin{array}{l}-0.005 \\
(0.466)\end{array}$ \\
\hline Observations & 1,686 & 1,683 & 1,683 & 1,683 \\
\hline
\end{tabular}

a dummy for males, level of education, being married, residence in the North and the Center (the South being the excluded category), and indicators of the individual income and wealth; to account for potential non-linear effects in endowment we include both linear and squared income and wealth. Interestingly, neither income or wealth affects 
Table 4 continued

\begin{tabular}{|c|c|c|c|c|}
\hline & No controls & Demographics & $\begin{array}{l}\text { Demographics } \\
\& \text { attitudes }\end{array}$ & $\begin{array}{l}\text { Demographics } \\
\& \text { attitudes }\end{array}$ \\
\hline \multicolumn{5}{|c|}{ Panel B: The "I do not know" are dropped from the sample } \\
\hline Accessibility & $\begin{array}{l}-0.076^{* * *} \\
(0.002)\end{array}$ & $\begin{array}{l}-0.083^{* * *} \\
(0.001)\end{array}$ & $\begin{array}{l}-0.082^{* * * *} \\
(0.001)\end{array}$ & $\begin{array}{l}-0.084 * * * \\
(0.001)\end{array}$ \\
\hline Age & & $\begin{array}{l}0.004 * * * \\
(0.000)\end{array}$ & $\begin{array}{l}0.004 * * * \\
(0.000)\end{array}$ & $\begin{array}{l}0.004 * * * \\
(0.000)\end{array}$ \\
\hline Male & & $\begin{array}{l}-0.087 * * * \\
(0.002)\end{array}$ & $\begin{array}{l}-0.077 * * * \\
(0.006)\end{array}$ & $\begin{array}{l}-0.077 * * * \\
(0.006)\end{array}$ \\
\hline Education & & $\begin{array}{l}-0.005^{*} \\
(0.090)\end{array}$ & $\begin{array}{l}-0.004 \\
(0.251)\end{array}$ & $\begin{array}{l}-0.003 \\
(0.356)\end{array}$ \\
\hline Married & & $\begin{array}{l}0.042 \\
(0.127)\end{array}$ & $\begin{array}{l}0.044 \\
(0.112)\end{array}$ & $\begin{array}{l}0.044 \\
(0.112)\end{array}$ \\
\hline North & & $\begin{array}{l}-0.040 \\
(0.195)\end{array}$ & $\begin{array}{l}-0.037 \\
(0.224)\end{array}$ & $\begin{array}{l}-0.030 \\
(0.335)\end{array}$ \\
\hline Centre & & $\begin{array}{l}-0.066^{*} \\
(0.063)\end{array}$ & $\begin{array}{l}-0.066^{*} \\
(0.063)\end{array}$ & $\begin{array}{l}-0.055 \\
(0.118)\end{array}$ \\
\hline City size & & $\begin{array}{l}-0.055^{* * *} \\
(0.000)\end{array}$ & $\begin{array}{l}-0.058^{* * * *} \\
(0.000)\end{array}$ & $\begin{array}{l}-0.057 * * * \\
(0.000)\end{array}$ \\
\hline Financial wealth & & $\begin{array}{l}-0.016 \\
(0.798)\end{array}$ & $\begin{array}{l}0.003 \\
(0.966)\end{array}$ & $\begin{array}{l}-0.008 \\
(0.898)\end{array}$ \\
\hline$(\text { Financial wealth })^{2}$ & & $\begin{array}{l}0.004 \\
(0.740)\end{array}$ & $\begin{array}{l}0.001 \\
(0.912)\end{array}$ & $\begin{array}{l}0.002 \\
(0.855)\end{array}$ \\
\hline Income & & $\begin{array}{l}-0.392 \\
(0.311)\end{array}$ & $\begin{array}{l}-0.304 \\
(0.436)\end{array}$ & $\begin{array}{l}-0.225 \\
(0.566)\end{array}$ \\
\hline$(\text { Income })^{2}$ & & $\begin{array}{l}0.247 \\
(0.728)\end{array}$ & $\begin{array}{l}0.105 \\
(0.884)\end{array}$ & $\begin{array}{l}-0.007 \\
(0.992)\end{array}$ \\
\hline Medium risk aversion & & & $\begin{array}{l}0.034 \\
(0.224)\end{array}$ & $\begin{array}{l}0.032 \\
(0.248)\end{array}$ \\
\hline High risk aversion & & & $\begin{array}{l}0.126^{* * *} \\
(0.000)\end{array}$ & $\begin{array}{l}0.125^{* * *} \\
(0.001)\end{array}$ \\
\hline Generalized trust & & & & $\begin{array}{l}-0.087 * * * \\
(0.002)\end{array}$ \\
\hline Subjective discount & & & & $\begin{array}{l}0.000 \\
(0.992)\end{array}$ \\
\hline Observations & 1,496 & 1,494 & 1,494 & 1,494 \\
\hline
\end{tabular}

This table shows marginal values of probit estimates of the probability of rejection of the small lottery. In panel A the left hand side is a dummy equal to 1 if the small lottery has been turned down; it is equal to zero if either had been accepted or the individual has answered "I do not know". In Panel B the left hand side is defined in the same way but those answering "I do not know are dropped from the sample. Accessibility is a variable equal to 1 if the lottery question was asked just after elicitation of the probability distribution of earnings one year-ahead and zero if asked at the beginning of the questionnaire. Coefficients are marginal effects of probit regressions. $p$ values are reported in parenthesis; *** significant at $1 \%$ or less, ** significant at $5 \%, *$ significant at $10 \%$ 
the chances of rejecting a small lottery, which suggests that people's tendency to turn down a small positive value lotteries does not vanish with wealth. However, age, marital status and city size all have significant effects. Married and older individuals and people living in smaller towns are more likely to reject it ${ }^{9}$; males and the better educated are less likely to turn down but their effect is not statistically significant.

The sign of education is consistent with Read et al. (1999) who conjecture that narrow framing can be a consequence of cognitive capacity limitations because combining risks together, particularly when they are many, is more difficult than assessing them one by one and so requires greater cognitive capacity, memory etc. But unlike Frederick (2005) and Benjamin et al. (2006) who find that cognitive ability lowers the rejection propensity, the estimated effect is not statistically significant. ${ }^{10}$ This result is similar to Rabin and Weizsacker (2009) who also find no significant effect of cognitive ability on the propensity to frame decisions narrowly.

But what is important is that the effect of accessibility is unaffected by these controls: the coefficient in column (2) is of similar magnitude as that obtained without controls. Of course, this is to be expected given the randomness of accessibility.

For a given degree of narrow framing, differences in risk attitudes may, as one would expect, explain variation in the willingness to accept the lottery. This conjecture receives support in the third column, where two dummies for individual risk aversion obtained from the qualitative indicator, excluding the group with low and very low risk aversion. Those with a preference for conservative financial decisions are also more likely to turn down the lottery than those who are more prepared to take financial risk, and the difference is substantial: $14.4 \%$ points - an effect equal to $24 \%$ of the average rejection rate in the sample. A similar result is obtained if I use the alternative measure of risk aversion. ${ }^{11}$

As we have seen uncertainty about the lottery is resolved after one year, so the gain or the loss comes a year after the interview. One may argue that delayed lotteries may be unappealing not because people frame decisions narrowly and are averse to losses but may because of lack of trust in the promise of payment. Alternatively, differences may reflect subjective discount rates if loss-sensitive individuals discount losses and gains differently. Though our test should not be affected by individual heterogeneity along these dimensions since it is based on random exposure to accessibility, these

\footnotetext{
9 Interpretation of the effect of some of the demographics is not straigthforward and may be consistent with more than one explanation. For instance, age may be picking up a well known tendency of risk taking to be higher among the young. As for the the effect of being married one possibility is that being married raises the rejection rate because effects of losses spill over to kids, making married people more sensitive to losses.

10 We have added as an extra control a direct measure of cognitive ability - self-reported ranking in performance in middle-school. This measure is highly correlated with the number of years of education. Hence when we add it the effect of education becomes smaller but retains its significance while the cognitive ability measure is not statistically significant.

11 Consumption commitments have been cited by Chetty and Szeidl (2007) as a potential explanation for high risk aversion over intermediate risks. However, consumption commitments cannot explain why people turn down small risks of the sort studied here. In fact, consumers with commitments behave as risk neutral vis-a-vis risks of this sort (Chetty and Szeidl 2007, Table II)
} 
possibilities can be taken into account by controlling for the indicator of generalized trust and the individual measure of subjective discount. Adding these regressors (see column 4) emerges that generalized trust has a strong negative and significant effect: those who trust have a 9-percentage-point lower probability of turning down the lottery ( $15 \%$ of the sample mean), a result consistent with the findings of Guiso et al. (2008) that untrusting people are less likely to invest in stocks. The indicator for subjective discount however, has no statistically significant effect, as should be the case if individuals discount gains and losses at the same rate. Most importantly, all these controls leave the effect of accessibility to pre-existing risks unaffected.

The second panel repeats the estimates, this time dropping all those who answered "don't know" to the small lottery question. The results are essentially invariant.

One may conjecture that making income risk accessible may also remind of other risks for those exposed to them, in particular capital income risk. To check this possibility we have estimated the especification in Table 4 (column 4) for the sample of people that have risky assets in their portfolio. We find evidence consistent with the conjecture. For this group the marginal effect of accessibility is -0.117 ( $p$ value $<$ $1 \%$ ), that is negative, highly significant and $30 \%$ larger than in the whole sample.

\subsection{Dealing with Some Objections}

Of course the lower rejection rate among those who are asked about the lottery after reporting their income risk may not reflect accessibility but some other effect that varies systematically with the location of the small lottery question. For instance, it may be argued that people may be less prone to turn down lotteries when they are tired, towards the end of the interview. Another, perhaps more compelling objection, is that the lower rejection rate among this group may actually reflect trust that interviewers build up as the interview proceeds, making participants more willing to accept the lottery. Though I control for trust, one may still object that this is a measure of generalized trust, not of the personal trust that the respondent develops for the interviewer, which may be what actually matters (even if unconsciously, since it is not the interviewer personally who promised to pay). For instance, some interviewers may at glance be perceived as less trustworthy than others, but this bias disappears as the interview proceeds and inference on the interviewer trustworthiness is made using elements other than their appearance. In this case those who answer the lottery question first may be more likely to turn it down than those who answer it later.

I address these issues in two ways. First, I show that the lower rejection rate in the second group is unlikely to reflect some unmeasured feature of the interview that happens to affect the lottery decision. Second, in the next section I show that the effect of accessibility varies in ways that are fully consistent with what narrow framing theory would predict.

One way to address the first objection-accessibility proxyies for tiredness-is to control for the length of the interview. If tiredness matters, one should find that longer interviews trigger different answers, and if the indicator of accessibility reflects tiredness it should lose significance. I account for this in Table 5, first column, adding the interview length (in minutes) as an additional control. According to the estimates 
Table 5 Robustness

\begin{tabular}{|c|c|c|c|c|}
\hline & $\begin{array}{l}\text { (1) } \\
\text { Probit }\end{array}$ & $\begin{array}{l}\text { (2) } \\
\text { Linear } \\
\text { probability }\end{array}$ & $\begin{array}{l}\text { (3) } \\
\text { Fixed effects }\end{array}$ & $\begin{array}{l}\text { (4) } \\
\text { Fixed effects }\end{array}$ \\
\hline Accessibility & $\begin{array}{l}-0.090^{* * * *} \\
(0.000)\end{array}$ & $\begin{array}{l}-0.086^{* * * *} \\
(0.000)\end{array}$ & $\begin{array}{l}-0.079 * * * \\
(0.001)\end{array}$ & $\begin{array}{l}-0.080 * * * \\
(0.000)\end{array}$ \\
\hline Age & $\begin{array}{l}0.003 * * \\
(0.016)\end{array}$ & $\begin{array}{l}0.003 * * \\
(0.012)\end{array}$ & $\begin{array}{l}0.003 * * * \\
(0.006)\end{array}$ & $\begin{array}{l}0.003 * * * \\
(0.004)\end{array}$ \\
\hline Male & $\begin{array}{l}-0.027 \\
(0.335)\end{array}$ & $\begin{array}{l}-0.031 \\
(0.253)\end{array}$ & $\begin{array}{l}-0.064 * * \\
(0.018)\end{array}$ & $\begin{array}{l}-0.064^{* *} \\
(0.018)\end{array}$ \\
\hline Education & $\begin{array}{l}-0.001 \\
(0.670)\end{array}$ & $\begin{array}{l}-0.002 \\
(0.453)\end{array}$ & $\begin{array}{l}-0.002 \\
(0.597)\end{array}$ & $\begin{array}{l}-0.002 \\
(0.564)\end{array}$ \\
\hline Married & $\begin{array}{l}0.064^{* *} \\
(0.019)\end{array}$ & $\begin{array}{l}0.060^{* * *} \\
(0.022)\end{array}$ & $\begin{array}{l}0.022 \\
(0.400)\end{array}$ & $\begin{array}{l}0.022 \\
(0.403)\end{array}$ \\
\hline North & $\begin{array}{l}-0.030 \\
(0.331)\end{array}$ & $\begin{array}{l}-0.033 \\
(0.269)\end{array}$ & $\begin{array}{l}0.000 \\
(.)\end{array}$ & $\begin{array}{l}0.000 \\
\text { (.) }\end{array}$ \\
\hline Centre & $\begin{array}{l}-0.044 \\
(0.209)\end{array}$ & $\begin{array}{l}-0.042 \\
(0.210)\end{array}$ & $\begin{array}{l}0.000 \\
(.)\end{array}$ & $\begin{array}{l}0.000 \\
\text { (.) }\end{array}$ \\
\hline City size & $\begin{array}{l}-0.043 * * * \\
(0.000)\end{array}$ & $\begin{array}{l}-0.042^{* * * *} \\
(0.000)\end{array}$ & $\begin{array}{l}-0.033 \\
(0.456)\end{array}$ & $\begin{array}{l}-0.034 \\
(0.448)\end{array}$ \\
\hline Financial wealth & $\begin{array}{l}0.018 \\
(0.783)\end{array}$ & $\begin{array}{l}0.016 \\
(0.796)\end{array}$ & $\begin{array}{l}0.010 \\
(0.877)\end{array}$ & $\begin{array}{l}0.006 \\
(0.926)\end{array}$ \\
\hline$(\text { Financial wealth })^{2}$ & $\begin{array}{l}0.000 \\
(0.988)\end{array}$ & $\begin{array}{l}0.000 \\
(0.984)\end{array}$ & $\begin{array}{l}0.001 \\
(0.969)\end{array}$ & $\begin{array}{l}0.001 \\
(0.931)\end{array}$ \\
\hline Income & $\begin{array}{l}-0.134 \\
(0.739)\end{array}$ & $\begin{array}{l}-0.122 \\
(0.755)\end{array}$ & $\begin{array}{l}-0.064 \\
(0.872)\end{array}$ & $\begin{array}{l}-0.054 \\
(0.890)\end{array}$ \\
\hline$(\text { Income })^{2}$ & $\begin{array}{l}-0.087 \\
(0.909)\end{array}$ & $\begin{array}{l}-0.114 \\
(0.877)\end{array}$ & $\begin{array}{l}-0.520 \\
(0.469)\end{array}$ & $\begin{array}{l}-0.527 \\
(0.463)\end{array}$ \\
\hline Medium risk aversion & $\begin{array}{l}0.046^{*} \\
(0.096)\end{array}$ & $\begin{array}{l}0.048^{*} \\
(0.080)\end{array}$ & $\begin{array}{l}0.012 \\
(0.668)\end{array}$ & $\begin{array}{l}0.013 \\
(0.641)\end{array}$ \\
\hline High risk aversion & $\begin{array}{l}0.147 * * * \\
(0.000)\end{array}$ & $\begin{array}{l}0.149 \text { *** } \\
(0.000)\end{array}$ & $\begin{array}{l}0.086^{* * *} \\
(0.021)\end{array}$ & $\begin{array}{l}0.088^{* *} \\
(0.019)\end{array}$ \\
\hline Generalized trust & $\begin{array}{l}-0.102 * * * \\
(0.000)\end{array}$ & $\begin{array}{l}-0.097 * * * \\
(0.000)\end{array}$ & $\begin{array}{l}-0.049 * \\
(0.081)\end{array}$ & $\begin{array}{l}-0.048^{*} \\
(0.089)\end{array}$ \\
\hline Subjective discount & $\begin{array}{l}-0.005 \\
(0.447)\end{array}$ & $\begin{array}{l}-0.004 \\
(0.512)\end{array}$ & $\begin{array}{l}-0.004 \\
(0.605)\end{array}$ & $\begin{array}{l}-0.004 \\
(0.567)\end{array}$ \\
\hline Length of interview & $\begin{array}{l}0.001 \\
(0.161)\end{array}$ & $\begin{array}{l}0.001 \\
(0.246)\end{array}$ & $\begin{array}{l}-0.000 \\
(0.780)\end{array}$ & $\begin{array}{l}-0.000 \\
(0.780)\end{array}$ \\
\hline Understading of questions & & $\begin{array}{l}0.008 \\
(0.519)\end{array}$ & $\begin{array}{l}-0.011 \\
(0.360)\end{array}$ & $\begin{array}{l}-0.009 \\
(0.458)\end{array}$ \\
\hline Easiness in answering questions & & $\begin{array}{l}0.001 \\
(0.952)\end{array}$ & $\begin{array}{l}0.002 \\
(0.886)\end{array}$ & $\begin{array}{l}0.006 \\
(0.646)\end{array}$ \\
\hline
\end{tabular}


Table 5 continued

\begin{tabular}{lllll}
\hline & $(1)$ & $(2)$ & $(3)$ & $(4)$ \\
& Probit & $\begin{array}{l}\text { Linear } \\
\text { probability }\end{array}$ & Fixed effects & Fixed effects \\
\hline Overall interview climate & & & -0.014 \\
Observations & 1,683 & 1,683 & 1,683 & $(0.204)$ \\
R-squared & & 0.053 & 0.303 & 1,683 \\
\hline
\end{tabular}

This table shows marginal values of probit estimates (column 1) and linear probability estimates (columns 2, 3 and 4) of the probability of rejection of the small lottery. The left hand side is a dummy equal to 1 if the small lottery has been turned down; it is equal to zero if either had been accepted or the individual has answered "I do not know". Accessibility is a variable equal to 1 if the lottery question was asked just after elicitation of the probability distribution of income one year-ahead and zero if asked at the beginning of the questionnaire. The last three variables are assessments of the interview as reported by the interviewer at the end of the interview. For probit estimates coefficients are marginal effects. $p$ values are reported in parenthesis; $* * *$ significant at $1 \%$ or less, $* *$ significant at $5 \%, *$ significant at $10 \%$

one standard deviation increase in interview length $(20 \mathrm{~min})$ raises the probability of refusing the lottery by $2 \%$ points but the effects is not statistically significant. In any case, the effect of accessibility is unchanged.

The second issue - trust generated during the interview - is addressed by a linear probability model with fixed effects for the interviewer to capture their perceived trustworthiness at the beginning of the interview and thus the slope of the evolution of trust towards them. The results are shown in column 3; for comparison column 2 shows the OLS estimates of the linear probability model. The fixed-effects for the interviewer are clearly important as the increase in the $R^{2}$ compared to the OLS estimates shows. However,the effect of accessibility is only mildly reduced-from 0.086 to 0.079 in absolute value, suggesting that interviewer trustworthiness does affect the lottery decision but is unlikely to change significantly over the course of the interview.

As an alternative check, the fourth column reports a regression controlling also for an index of the overall climate of the interview: this is a judgement reported on a scale from 1 (poor climate) to 10 (very good climate) by the interviewer at the end of the interview. Respondents mistrust and reluctance to answer should be reflected in this index. As the estimates in column 4 show, the interview climate has no effect on the lottery decision and including it does not alter the effect of the indicator of accessibility. Adding similarly obtained measures of whether the survey participants understood the questions and whether they found it easy to answer (in columns 2, 3 and 4) also has no effect on the estimates.

\subsection{The Effect of Pre-existing Risk}

To further test whether accessibility is really capturing variation in the degree of narrow framing and not some other effect (including evolution in personalized trust during the interview), variation in perceived uncertainty can be exploited. In the UCS some 
respondents face no income risk (the minimum and maximum earnings one year ahead coincide). For the retired this is obvious as they receive a social security pension whose amount is known in advance. For the others, about $30 \%$ report no uncertainty, with a smaller proportion among the self-employed than among the employees, particularly public sector employees.

If pre-existing risk is what makes the lottery more attractive, then we should find that: (a) those facing income risk are less likely to turn down the lottery; (b) income risk matters more (will be more negative) for those who have greater accessibility to it and are thus more able to visualize the diversification benefits of the lottery. ${ }^{12}$ I thus define an indicator that is equal to 1 if the range of the subjective probability distribution of one year ahead earnings is different from zero and then use this indicator and its interaction with the identifier for accessibility as explanatory variables in the probability of turning down the lottery.

Table 6 shows the results. Inserting the income risk indicator alone (column 1) it has a negative effect on the probability of turning down the lottery, as it should if individuals at least partially mix the lottery with their pre-existing labor income risk. Obviously, since earnings risk is correlated with other attributes of the individual that may discourage lottery participation directly, it is crucial to control for such attributes. ${ }^{13}$ Those facing an uncertain income have a 6.3-percentage-points lower probability of turning down the lottery. This is the average effect for the whole sample. However, adding also the interaction between the uncertainty indicator and the accessibility indicator (column 2), I find that pre-existing risk only matters for the group that has access to it - that is, those who answer the lottery question after the subjective earnings question. For this group, facing an uncertain income lowers the probability of turning down the lottery by $10.5 \%$ points; for those with limited accessibility it has no effect, implying that they ignore it altogether when deciding about the lottery. Columns 3 and 4 report the estimates when instead of interacting uncertainty with accessibility I run separate regressions for high and low accessibility; this flexible specification implicitely allows for accessibility to have a direct effect on the mean take up rate as well as to affect interactively all the other explanatory variables. These estimates confirm that income uncertainty only matters when individuals are given access to it. ${ }^{14}$

Since the earnings uncertainty question is only answered by those currently working while the retired are assumed to face no income uncertainty out of the fact that

\footnotetext{
12 If some perceive no income risk, this could explain why evoking their pre-existing risks may have a limited impact on the probability of turning the lottery down. Exposing this people to their income uncertainty does not make the small lottery more attractive.

13 Notably, more risk-averse individuals are more likely to choose safer jobs and hence are less likely to face uncertain labor income. Income risk may thus capture risk aversion if the latter is omitted from the regression or is mis-measured.

14 Interestingly, risk aversion has a stronger effect on the rejection rate for those with low accessibility, and thus a higher degree of narrow framing, following our formulation in Sect. 2. In so far the measure of risk aversion is positively correlated with loss aversion this is consistent with the narrow framing model. In fact, a higher loss aversion lowers the chances of accepting the lottery because it reduces its expected value $E v(\widetilde{x})$ but the overll effect on the acceptance rate depends on $b$ - the degree of narrow framing-which weigth the expected value of the lottery as shown in Sect. 2.
} 
Table 6 Pre-existing income risk and the rejection of a small beneficial lottery

\begin{tabular}{|c|c|c|c|c|c|c|c|}
\hline & $\begin{array}{l}\text { (1) } \\
\text { Whole } \\
\text { sample }\end{array}$ & $\begin{array}{l}(2) \\
\text { Whole } \\
\text { sample }\end{array}$ & $\begin{array}{l}\text { (3) } \\
\text { High } \\
\text { accessibility }\end{array}$ & $\begin{array}{l}\text { (4) } \\
\text { Low } \\
\text { accessibility }\end{array}$ & $\begin{array}{l}(5) \\
\text { No } \\
\text { retired }\end{array}$ & $\begin{array}{l}(6) \\
\text { No } \\
\text { retired }\end{array}$ & $\begin{array}{l}\text { (7) } \\
\text { No } \\
\text { retired }\end{array}$ \\
\hline $\begin{array}{l}\text { Income } \\
\text { uncertainty }\end{array}$ & $\begin{array}{l}-0.063 * * \\
(0.024)\end{array}$ & $\begin{array}{l}-0.003 \\
(0.931)\end{array}$ & $\begin{array}{l}-0.071^{* *} \\
(0.039)\end{array}$ & $\begin{array}{l}-0.040 \\
(0.216)\end{array}$ & $\begin{array}{l}0.019 \\
(0.648)\end{array}$ & & $\begin{array}{l}0.018 \\
(0.668)\end{array}$ \\
\hline $\begin{array}{r}\text { Uncertainty } \times \\
\text { accessibility }\end{array}$ & & $\begin{array}{l}-0.105^{* * *} \\
(0.006)\end{array}$ & & & $\begin{array}{l}-0.115^{* * *} \\
(0.003)\end{array}$ & & $\begin{array}{l}-0.115^{* * * *} \\
(0.003)\end{array}$ \\
\hline $\begin{array}{l}\text { Expected } \\
\text { income }\end{array}$ & & & & & & $\begin{array}{l}-0.000 \\
(0.849)\end{array}$ & $\begin{array}{l}-0.000 \\
(0.780)\end{array}$ \\
\hline $\begin{array}{l}\text { Expected } \\
\text { income } \times \\
\text { accessibility }\end{array}$ & & & & & & $\begin{array}{l}0.000 \\
(0.900)\end{array}$ & $\begin{array}{l}0.000 \\
(0.907)\end{array}$ \\
\hline Age & $\begin{array}{l}0.001 \\
(0.236)\end{array}$ & $\begin{array}{l}0.002 \\
(0.188)\end{array}$ & $\begin{array}{l}0.002 \\
(0.173)\end{array}$ & $\begin{array}{l}0.001 \\
(0.702)\end{array}$ & $\begin{array}{l}0.002 \\
(0.241)\end{array}$ & $\begin{array}{l}0.002 \\
(0.257)\end{array}$ & $\begin{array}{l}0.002 \\
(0.248)\end{array}$ \\
\hline Male & $\begin{array}{l}-0.021 \\
(0.457)\end{array}$ & $\begin{array}{l}-0.023 \\
(0.404)\end{array}$ & $\begin{array}{l}0.013 \\
(0.734)\end{array}$ & $\begin{array}{l}-0.053 \\
(0.182)\end{array}$ & $\begin{array}{l}-0.004 \\
(0.921)\end{array}$ & $\begin{array}{l}0.000 \\
(1.000)\end{array}$ & $\begin{array}{l}-0.004 \\
(0.923)\end{array}$ \\
\hline Education & $\begin{array}{l}-0.001 \\
(0.765)\end{array}$ & $\begin{array}{l}-0.000 \\
(0.887)\end{array}$ & $\begin{array}{l}0.003 \\
(0.546)\end{array}$ & $\begin{array}{l}-0.005 \\
(0.258)\end{array}$ & $\begin{array}{l}0.005 \\
(0.287)\end{array}$ & $\begin{array}{l}0.004 \\
(0.355)\end{array}$ & $\begin{array}{l}0.005 \\
(0.290)\end{array}$ \\
\hline Married & $\begin{array}{l}0.068^{* *} \\
(0.012)\end{array}$ & $\begin{array}{l}0.068^{* *} \\
(0.012)\end{array}$ & $\begin{array}{l}0.074 * \\
(0.052)\end{array}$ & $\begin{array}{l}0.053 \\
(0.173)\end{array}$ & $\begin{array}{l}0.035 \\
(0.327)\end{array}$ & $\begin{array}{l}0.034 \\
(0.336)\end{array}$ & $\begin{array}{l}0.036 \\
(0.320)\end{array}$ \\
\hline North & $\begin{array}{l}-0.026 \\
(0.399)\end{array}$ & $\begin{array}{l}-0.024 \\
(0.436)\end{array}$ & $\begin{array}{l}-0.049 \\
(0.254)\end{array}$ & $\begin{array}{l}0.000 \\
(0.992)\end{array}$ & $\begin{array}{l}-0.004 \\
(0.917)\end{array}$ & $\begin{array}{l}-0.006 \\
(0.882)\end{array}$ & $\begin{array}{l}-0.003 \\
(0.930)\end{array}$ \\
\hline Centre & $\begin{array}{l}-0.037 \\
(0.287)\end{array}$ & $\begin{array}{l}-0.040 \\
(0.253)\end{array}$ & $\begin{array}{l}-0.099 * * \\
(0.045)\end{array}$ & $\begin{array}{l}0.031 \\
(0.522)\end{array}$ & $\begin{array}{l}-0.053 \\
(0.228)\end{array}$ & $\begin{array}{l}-0.047 \\
(0.288)\end{array}$ & $\begin{array}{l}-0.053 \\
(0.228)\end{array}$ \\
\hline City size & $\begin{array}{l}-0.046^{* * *} \\
(0.000)\end{array}$ & $\begin{array}{l}-0.046^{* * *} \\
(0.000)\end{array}$ & $\begin{array}{l}-0.051 * * * \\
(0.001)\end{array}$ & $\begin{array}{l}-0.043 * * * \\
(0.004)\end{array}$ & $\begin{array}{l}-0.069^{* * *} \\
(0.000)\end{array}$ & $\begin{array}{l}-0.068 * * * \\
(0.000)\end{array}$ & $\begin{array}{l}-0.069 * * * \\
(0.000)\end{array}$ \\
\hline $\begin{array}{c}\text { Financial } \\
\text { wealth }\end{array}$ & $\begin{array}{l}0.021 \\
(0.750)\end{array}$ & $\begin{array}{l}0.021 \\
(0.748)\end{array}$ & $\begin{array}{l}0.096 \\
(0.298)\end{array}$ & $\begin{array}{l}0.018 \\
(0.882)\end{array}$ & $\begin{array}{l}0.087 \\
(0.306)\end{array}$ & $\begin{array}{l}0.091 \\
(0.288)\end{array}$ & $\begin{array}{l}0.088 \\
(0.304)\end{array}$ \\
\hline $\begin{array}{l}\text { (Financial } \\
\text { wealth) }^{2}\end{array}$ & $\begin{array}{l}-0.001 \\
(0.939)\end{array}$ & $\begin{array}{l}-0.001 \\
(0.957)\end{array}$ & $\begin{array}{l}-0.008 \\
(0.619)\end{array}$ & $\begin{array}{l}-0.018 \\
(0.655)\end{array}$ & $\begin{array}{l}-0.009 \\
(0.563)\end{array}$ & $\begin{array}{l}-0.010 \\
(0.541)\end{array}$ & $\begin{array}{l}-0.009 \\
(0.558)\end{array}$ \\
\hline Income & $\begin{array}{l}-0.153 \\
(0.704)\end{array}$ & $\begin{array}{l}-0.136 \\
(0.736)\end{array}$ & $\begin{array}{l}-1.301 * * \\
(0.044)\end{array}$ & $\begin{array}{l}0.653 \\
(0.236)\end{array}$ & $\begin{array}{l}-0.505 \\
(0.340)\end{array}$ & $\begin{array}{l}-0.536 \\
(0.311)\end{array}$ & $\begin{array}{l}-0.501 \\
(0.345)\end{array}$ \\
\hline$(\text { Income })^{2}$ & $\begin{array}{l}-0.023 \\
(0.976)\end{array}$ & $\begin{array}{l}-0.068 \\
(0.928)\end{array}$ & $\begin{array}{l}2.375^{*} \\
(0.084)\end{array}$ & $\begin{array}{l}-1.468 \\
(0.151)\end{array}$ & $\begin{array}{l}0.450 \\
(0.642)\end{array}$ & $\begin{array}{l}0.530 \\
(0.586)\end{array}$ & $\begin{array}{l}0.444 \\
(0.647)\end{array}$ \\
\hline $\begin{array}{l}\text { Medium risk } \\
\text { aversion }\end{array}$ & $\begin{array}{l}0.047 * \\
(0.088)\end{array}$ & $\begin{array}{l}0.047 * \\
(0.090)\end{array}$ & $\begin{array}{l}0.055 \\
(0.163)\end{array}$ & $\begin{array}{l}0.056 \\
(0.162)\end{array}$ & $\begin{array}{l}0.071 * * \\
(0.047)\end{array}$ & $\begin{array}{l}0.070 * * \\
(0.048)\end{array}$ & $\begin{array}{l}0.070 * * \\
(0.048)\end{array}$ \\
\hline $\begin{array}{l}\text { High risk } \\
\text { aversion }\end{array}$ & $\begin{array}{l}0.145^{* * *} \\
(0.000)\end{array}$ & $\begin{array}{l}0.146^{* * * *} \\
(0.000)\end{array}$ & $\begin{array}{l}0.115^{* *} \\
(0.025)\end{array}$ & $\begin{array}{l}0.184 * * * \\
(0.000)\end{array}$ & $\begin{array}{l}0.173 * * * \\
(0.000)\end{array}$ & $\begin{array}{l}0.170^{* * *} \\
(0.001)\end{array}$ & $\begin{array}{l}0.173 * * * \\
(0.000)\end{array}$ \\
\hline $\begin{array}{l}\text { Generalized } \\
\text { trust }\end{array}$ & $\begin{array}{l}-0.099 * * * \\
(0.000)\end{array}$ & $\begin{array}{l}-0.099 * * * \\
(0.000)\end{array}$ & $\begin{array}{l}-0.082 * * \\
(0.037)\end{array}$ & $\begin{array}{l}-0.110 * * * \\
(0.005)\end{array}$ & $\begin{array}{l}-0.097 * * * \\
(0.007)\end{array}$ & $\begin{array}{l}-0.095 * * * \\
(0.008)\end{array}$ & $\begin{array}{l}-0.097 * * * \\
(0.007)\end{array}$ \\
\hline
\end{tabular}


Table 6 continued

\begin{tabular}{llllllll}
\hline & $(1)$ & $(2)$ & $(3)$ & $(4)$ & $(5)$ & $(6)$ & $(7)$ \\
& $\begin{array}{l}\text { Whole } \\
\text { sample }\end{array}$ & $\begin{array}{l}\text { Whole } \\
\text { sample }\end{array}$ & $\begin{array}{l}\text { High } \\
\text { accessibility }\end{array}$ & $\begin{array}{l}\text { Low } \\
\text { accessibility }\end{array}$ & $\begin{array}{l}\text { No } \\
\text { retired }\end{array}$ & $\begin{array}{l}\text { No } \\
\text { retired }\end{array}$ & $\begin{array}{l}\text { No } \\
\text { retired }\end{array}$ \\
\hline $\begin{array}{l}\text { Subjective } \\
\text { discount }\end{array}$ & -0.005 & -0.005 & 0.006 & $-0.019^{*}$ & 0.008 & 0.006 & 0.008 \\
& $(0.442)$ & $(0.504)$ & $(0.543)$ & $(0.056)$ & $(0.386)$ & $(0.464)$ & $(0.378)$ \\
Observations & 1,683 & 1,683 & 885 & 798 & 1,009 & 1,009 & 1,009 \\
\hline
\end{tabular}

This table shows marginal values of probit estimates of the effect of income risk on the probability of rejection of the small lottery. The left hand side is a dummy equal to 1 if the small lottery has been turned down; it is equal to zero if either has been accepted or the individual has answered "I do not know". Income uncertainty is a dummy equal to 1 if the expected maximum income one year ahead exceeds the minimum and zero if the two coincide. Accessibility is a variable equal to 1 if the lottery question was asked just after elicitation of the probability distribution of income one year-ahead and zero if asked at the beginning of the questionnaire. Coefficients are marginal effects of probit regressions. $p$ values are reported in parenthesis; $* * *$ significant at $1 \%$ or less, $* *$ significant at $5 \%, *$ significant at $10 \%$

their pension is fully predictable, in column (5) I check the results by dropping the retired. Results are robust to re-estimating only on the current employed and income uncertainty lowers the rejection rate only for those who have access to it.

One may argue that narrow framing is not about uncertainty but about income or wealth levels. We can check this possibility by controlling for expected income and expected income interacted with accessibility. In column (6) we replace the income uncertainty indicator (alone and interacted with accessibility) with expected income (alone and interacted) and find that the expected income has no effect on the decision to reject the lottery. Adding also uncertainty (column 7) shows that only the latter matters suggesting that giving access to pre-existing risk encourages lottery acceptance because it makes it easier to see its diversification benefits.

Taken together these results are consistent with the hypothesis that the first group frames the small lottery decision completely in isolation, whereas those with greater accessibility seem to be at least partially combining that decision with a consideration of pre-existing risk and thus enjoying the diversification benefits that the small lottery entails. But again, even among those facing uncertainty and being made aware of it, many continue to turn down the lottery and behave like those who have no access to pre-existing risks. One possibility is that this is a reflection of a mode of thinking that forges the tendency to frame decisions in isolation. I now turn to this issue.

\section{What Does Determine Narrow Framing?}

As is argued in Sect. 2.1 narrow framing may reflect individuals' propensity to regret. Since regret refers to a specific action/choice, it naturally leads to a focus on the consequences that are most immediately linked to the action, giving rise to narrowly framed decisions. Hence, a regret-based explanation predicts that regret-prone individuals are more likely to turn down the lottery if they regret losses more deeply, to accept it if they regret mainly missed gains. 
Alternatively, narrow framing could be the reflection of reliance on intuition in deciding whether or not to accept an uncertain prospect. According to dual decision models, intuitive thinking focuses on the specific elements that characterize the prospect itself, such as return and variance or losses and gains, and ignore possible interactions it may have with other components of individual wealth. In our context the most visible (accessible) features of the lottery are the size of the gain and the loss and their probabilities. Its lack of correlation with pre-existing risk (and thus its potential diversification benefit) remains in the background and may be ignored by intuitive thinkers. Intuitive decisions are in fact heavily affected by the most superficial and readily accessible elements of the lottery (Kahneman 2003). On the other hand, individuals who rely mostly on reasoning can see beyond the veil of the superficial features of the lottery and put it in perspective, capturing its relation with other components of wealth.

Interestingly, these two theories of narrow framing are likely to rest on different mechanisms. In particular, since regret is a prominent form of counterfactual thinking whereby the decision maker, at time of deciding, compares the prospective "what might have been" alternative (the counterfactual) with "what has effectively been", one may argue that it involves very sophisticated and effortful reasoning rather than intuition, though reasoning is captured by the particular object of choice. In fact, in our sample regret indicators are positively correlated with reliance (total or partial) on reasoning as the typical mode of thinking when making decisions.

\subsection{The Role of Regret}

Table 7 examines the role of regret. When the indicators of regret about losses and gains are added to the specifications shown in Table 4, they are both significant. Regret about losses incurred makes one more likely to turn the lottery down (column 1); all else constant, those who deeply regret a loss are $10 \%$ points more likely than those who feel no regret to turn down the lottery. On the other hand, regret about missed gains has a negative and significant effect on the rejection rate and the effect is more than twice as large as that of regret about losses. Compared to those who do not regret a missed gain, those who regret it deeply are $23.5 \%$ points less likely to turn the lottery down (more than one third of the unconditional rejection rate). On the other hand adding regret as a control leaves the effect of accessibility to pre-existing risks unaffected.

In the second column I add a battery of demographic controls and risk attitudes. Interestingly, the effect of regret is unchanged even controlling for the individual risk aversion and for other demographics, and the effect of accessibility is also unaltered. In the third column I add the indicator of generalized trust, mistrust may be a reflection of regret. Even in this case, however, the effect of regret remains unchanged and trust retains it effect, both economically and statistically. This suggests that regret, trust and risk aversion affect the willingness to participate in small advantageous lotteries through different channels. In particular, the results are consistent with regret being an important cause of narrow framing. 
Table 7 Assessing the role of regret

This table shows marginal values of probit estimates of the effect of regret on the decision to turn the small lottery down. Regret losses is an indicator comprised between 1 and 3 of the intensity an individual regrets an incurred loss that could have been avoided, where 1 stands for no regret, 2 for some regret and 3 for a "regret a lot"; the variable Regret missed gain has a similar interpretation but with respect to a gain that could have been obtained but has been missed. Accessibility is a variable equal to 1 if the lottery question was asked just after elicitation of the probability distribution of income one year-ahead. Coefficients are marginal effects of probit regressions. $p$ values are reported in parenthesis; $* * *$ significant at $1 \%$ or less, $* *$ significant at $5 \%$, * significant at $10 \%$
(1) (2)

(3)

\begin{tabular}{|c|c|c|c|}
\hline $\begin{array}{l}\text { Accessibility to } \\
\text { pre-existing risk }\end{array}$ & $\begin{array}{l}-0.078 * * * \\
(0.001)\end{array}$ & $\begin{array}{l}-0.083^{* * *} \\
(0.001)\end{array}$ & $\begin{array}{l}-0.085^{* * *} \\
(0.000)\end{array}$ \\
\hline Regret losses & $\begin{array}{l}0.051 * * * \\
(0.003)\end{array}$ & $\begin{array}{l}0.050 * * * \\
(0.005)\end{array}$ & $\begin{array}{l}0.048 * * * \\
(0.008)\end{array}$ \\
\hline Regret missed gain & $\begin{array}{l}-0.117 * * * \\
(0.000)\end{array}$ & $\begin{array}{l}-0.104 * * * \\
(0.000)\end{array}$ & $\begin{array}{l}-0.102^{* * * *} \\
(0.000)\end{array}$ \\
\hline Age & & $\begin{array}{l}0.002 * * \\
(0.048)\end{array}$ & $\begin{array}{l}0.002 * * \\
(0.045)\end{array}$ \\
\hline Male & & $\begin{array}{l}-0.026 \\
(0.349)\end{array}$ & $\begin{array}{l}-0.027 \\
(0.329)\end{array}$ \\
\hline Education & & $\begin{array}{l}-0.003 \\
(0.345)\end{array}$ & $\begin{array}{l}-0.002 \\
(0.474)\end{array}$ \\
\hline Married & & $\begin{array}{l}0.057 * * \\
(0.035)\end{array}$ & $\begin{array}{l}0.057 * * \\
(0.035)\end{array}$ \\
\hline North & & $\begin{array}{l}-0.038 \\
(0.218)\end{array}$ & $\begin{array}{l}-0.030 \\
(0.337)\end{array}$ \\
\hline Centre & & $\begin{array}{l}-0.057 \\
(0.106)\end{array}$ & $\begin{array}{l}-0.046 \\
(0.196)\end{array}$ \\
\hline City size & & $\begin{array}{l}-0.047 * * * \\
(0.000)\end{array}$ & $\begin{array}{l}-0.047^{* * *} \\
(0.000)\end{array}$ \\
\hline Financial wealth & & $\begin{array}{l}0.032 \\
(0.618)\end{array}$ & $\begin{array}{l}0.016 \\
(0.800)\end{array}$ \\
\hline $\begin{array}{l}\text { (Financial } \\
\text { wealth })^{2}\end{array}$ & & $\begin{array}{l}-0.001 \\
(0.956)\end{array}$ & $\begin{array}{l}0.001 \\
(0.939)\end{array}$ \\
\hline Income & & $\begin{array}{l}-0.204 \\
(0.613)\end{array}$ & $\begin{array}{l}-0.127 \\
(0.754)\end{array}$ \\
\hline$(\text { Income })^{2}$ & & $\begin{array}{l}0.042 \\
(0.956)\end{array}$ & $\begin{array}{l}-0.069 \\
(0.928)\end{array}$ \\
\hline $\begin{array}{l}\text { Medium risk } \\
\text { aversion }\end{array}$ & & $\begin{array}{l}0.025 \\
(0.379)\end{array}$ & $\begin{array}{l}0.025 \\
(0.386)\end{array}$ \\
\hline High risk aversion & & $\begin{array}{l}0.121 * * * \\
(0.001)\end{array}$ & $\begin{array}{l}0.121 * * * \\
(0.001)\end{array}$ \\
\hline Generalized trust & & & $\begin{array}{l}-0.097^{* * * *} \\
(0.001)\end{array}$ \\
\hline $\begin{array}{r}\text { Subjective } \\
\text { discount }\end{array}$ & & & $\begin{array}{l}-0.003 \\
(0.640)\end{array}$ \\
\hline Observations & 1,686 & 1,683 & 1,683 \\
\hline
\end{tabular}




\subsection{The Role of Intuition and Reasoning}

Table 8 investigates the second possible source of narrow framing: reliance on intuitive thinking rather than reasoning. The implication here is that the effect of accessibility to pre-existing risk on the willingness to accept the lottery should be stronger, the more the individual relies on reasoning. To test this prediction I identify three groups: those who rely mostly on intuition; those who rely on both intuition and reasoning and those who rely mostly on reasoning. Under the null hypothesis that this theory of narrow framing is true, one should find that the effect of accessibility is greatest for the third group. ${ }^{15}$

For comparison, the first column shows the results for the whole sample. The second column runs the regression on the subsample of those who rely mostly on intuition. Interestingly, for them facilitated access to pre-existing risk has no effect on willingness to accept the lottery. Those who rely partly on intuition and partly on reasoning (column three) respond to accessibility significantly, lowering the rejection rate by $7.6 \%$ points. This effect is smaller than for the whole sample but much larger (in absolute value) than for the sample of intuitive thinkers (first column). The effect of accessibility is even stronger for the group that relies mostly on reasoning: for them, readier accessibility to pre-existing risks lowers the rejection rate by $12.1 \%$ pointsan effect that is $60 \%$ greater than for those who combine intuition and reasoning. These findings support the idea that reasoning helps to de-contextualize the decision about a risky prospect and enables one to better appreciate its potential benefits.

One may suspect that thinking mode is actually a proxy for cognitive ability and that people with greater cognitive capacity rely more on reasoning and are thus better able to realize the diversification opportunities entailed by the small lottery. This is not actually the case, however. First, the indicator of thinking mode is poorly correlated both with education and with the self-reported measure of relative performance in secondary school; and even this poor correlation is, if anything negative with respect to both indicators. That is, those who rely on reasoning are actually a bit less well

\footnotetext{
15 One may argue that the opposite implication may be true, that is that people who rely on reasoning are the least sensitive to increased accessibility because they could have already discounted the benefits of mixing the lottery with the pre-existing risk they face. As a consequence making the latter more salient has no impact on their choice whereas it could affect the choice of those who rely on intuition. The data actually suggest that this is not the case and that even those who rely on reasoning, unless alerted about pre-existing risks, ignore them when deciding about the small lottery. If indeed those who rely on reasoning have already pre-viewed the benefits of mixing even when non-treated then I should find (ceteris paribus) a lower rejection rate for those who rely on reasoning and that decide about the lottery before being asked to think and report their income risk. When I run a regression of the rejection decision on thinking mode in the group of non treated, I find that those who rely on reasoning have the same rejection rate as those who rely on intuition. Another way of checking that those who rely on reasoning have not pre-viewed the benefits of mixing is to compare the rejection of this group when non treated and this same group but restricting to those that, when asked, report a positive income uncertainty. If they actually pre-viewed their income uncertainty the rejection rate should be lower for those who report income uncertainty. Instead I find no difference (the rejection rate is 69.8 and $69.6 \%$ in the two groups, respectively). All the action comes from the treatment: in fact the rejection rates for those who rely on reasoning and are treated is $57 \%$ for the whole group and $46 \%$ when I restrict the group to those who actually face income risk. One possible explanation is that people in our sample do not frequently encounter decisions of this type, or at least not represented in this way and so even hard thinkers frame then narrowly.
} 
Table 8 Intuitive thinking, reasoning and the effect on narrow framing

\begin{tabular}{|c|c|c|c|c|}
\hline & (1) & (2) & (3) & (4) \\
\hline & Total sample & $\begin{array}{l}\text { Rely only } \\
\text { on intuition }\end{array}$ & $\begin{array}{l}\text { Both intuition } \\
\text { and reasoning }\end{array}$ & $\begin{array}{l}\text { Mostly on } \\
\text { reasoning }\end{array}$ \\
\hline $\begin{array}{l}\text { Accessibility to } \\
\text { pre-existing risk }\end{array}$ & $\begin{array}{l}-0.085^{* * *} \\
(0.000)\end{array}$ & $\begin{array}{l}0.032 \\
(0.625)\end{array}$ & $\begin{array}{l}-0.076^{* *} \\
(0.044)\end{array}$ & $\begin{array}{l}-0.120^{\text {**** }} \\
(0.001)\end{array}$ \\
\hline Regret losses & $\begin{array}{l}0.048 * * * \\
(0.008)\end{array}$ & $\begin{array}{l}-0.045 \\
(0.350)\end{array}$ & $\begin{array}{l}0.059^{* *} \\
(0.046)\end{array}$ & $\begin{array}{l}0.068^{* *} \\
(0.010)\end{array}$ \\
\hline $\begin{array}{l}\text { Regret missed } \\
\text { gain }\end{array}$ & $\begin{array}{l}-0.102 * * * \\
(0.000)\end{array}$ & $\begin{array}{l}-0.060 \\
(0.329)\end{array}$ & $\begin{array}{l}-0.090^{* * * *} \\
(0.010)\end{array}$ & $\begin{array}{l}-0.111^{* * *} \\
(0.000)\end{array}$ \\
\hline Age & $\begin{array}{l}0.002^{* *} \\
(0.045)\end{array}$ & $\begin{array}{l}0.001 \\
(0.811)\end{array}$ & $\begin{array}{l}0.003 * \\
(0.082)\end{array}$ & $\begin{array}{l}0.003 * \\
(0.075)\end{array}$ \\
\hline Male & $\begin{array}{l}-0.027 \\
(0.329)\end{array}$ & $\begin{array}{l}0.000 \\
(0.997)\end{array}$ & $\begin{array}{l}-0.023 \\
(0.584)\end{array}$ & $\begin{array}{l}-0.038 \\
(0.386)\end{array}$ \\
\hline Education & $\begin{array}{l}-0.002 \\
(0.474)\end{array}$ & $\begin{array}{l}-0.007 \\
(0.436)\end{array}$ & $\begin{array}{l}-0.008 \\
(0.120)\end{array}$ & $\begin{array}{l}0.006 \\
(0.210)\end{array}$ \\
\hline Married & $\begin{array}{l}0.057^{* *} \\
(0.035)\end{array}$ & $\begin{array}{l}0.052 \\
(0.478)\end{array}$ & $\begin{array}{l}0.096^{* *} \\
(0.020)\end{array}$ & $\begin{array}{l}0.010 \\
(0.824)\end{array}$ \\
\hline North & $\begin{array}{l}-0.030 \\
(0.337)\end{array}$ & $\begin{array}{l}-0.053 \\
(0.556)\end{array}$ & $\begin{array}{l}-0.068 \\
(0.171)\end{array}$ & $\begin{array}{l}0.013 \\
(0.778)\end{array}$ \\
\hline Centre & $\begin{array}{l}-0.046 \\
(0.196)\end{array}$ & $\begin{array}{l}-0.047 \\
(0.658)\end{array}$ & $\begin{array}{l}-0.044 \\
(0.425)\end{array}$ & $\begin{array}{l}-0.067 \\
(0.208)\end{array}$ \\
\hline City size & $\begin{array}{l}-0.047 * * * \\
(0.000)\end{array}$ & $\begin{array}{l}-0.071 * * \\
(0.038)\end{array}$ & $\begin{array}{l}-0.038^{* *} \\
(0.022)\end{array}$ & $\begin{array}{l}-0.053^{* * * *} \\
(0.001)\end{array}$ \\
\hline Financial wealth & $\begin{array}{l}0.016 \\
(0.800)\end{array}$ & $\begin{array}{l}-0.109 \\
(0.494)\end{array}$ & $\begin{array}{l}0.078 \\
(0.462)\end{array}$ & $\begin{array}{l}-0.129 \\
(0.401)\end{array}$ \\
\hline $\begin{array}{l}\text { (Financial } \\
\text { wealth }^{2}\end{array}$ & $\begin{array}{l}0.001 \\
(0.939)\end{array}$ & $\begin{array}{l}0.036 \\
(0.453)\end{array}$ & $\begin{array}{l}-0.016 \\
(0.449)\end{array}$ & $\begin{array}{l}0.081 \\
(0.305)\end{array}$ \\
\hline Income & $\begin{array}{l}-0.127 \\
(0.754)\end{array}$ & $\begin{array}{l}-0.349 \\
(0.782)\end{array}$ & $\begin{array}{l}-0.076 \\
(0.905)\end{array}$ & $\begin{array}{l}-0.027 \\
(0.970)\end{array}$ \\
\hline$(\text { Income })^{2}$ & $\begin{array}{l}-0.069 \\
(0.928)\end{array}$ & $\begin{array}{l}-1.370 \\
(0.680)\end{array}$ & $\begin{array}{l}-0.121 \\
(0.919)\end{array}$ & $\begin{array}{l}0.792 \\
(0.638)\end{array}$ \\
\hline $\begin{array}{l}\text { Medium risk } \\
\text { aversion }\end{array}$ & $\begin{array}{l}0.025 \\
(0.386)\end{array}$ & $\begin{array}{l}-0.064 \\
(0.386)\end{array}$ & $\begin{array}{l}0.074 * \\
(0.088)\end{array}$ & $\begin{array}{l}0.006 \\
(0.904)\end{array}$ \\
\hline High risk aversion & $\begin{array}{l}0.121 * * * \\
(0.001)\end{array}$ & $\begin{array}{l}-0.008 \\
(0.938)\end{array}$ & $\begin{array}{l}0.175^{* * * *} \\
(0.003)\end{array}$ & $\begin{array}{l}0.110^{* *} \\
(0.050)\end{array}$ \\
\hline Generalized trust & $\begin{array}{l}-0.097 * * * \\
(0.001)\end{array}$ & $\begin{array}{l}-0.161^{* *} \\
(0.030)\end{array}$ & $\begin{array}{l}-0.113 * * * \\
(0.007)\end{array}$ & $\begin{array}{l}-0.045 \\
(0.350)\end{array}$ \\
\hline
\end{tabular}


Table 8 continued

\begin{tabular}{lllll}
\hline & $(1)$ & $(2)$ & $(3)$ & $(4)$ \\
Total sample & $\begin{array}{l}\text { Rely only } \\
\text { on intuition }\end{array}$ & $\begin{array}{l}\text { Both intuition } \\
\text { and reasoning }\end{array}$ & $\begin{array}{l}\text { Mostly on } \\
\text { reasoning }\end{array}$ \\
\hline $\begin{array}{c}\text { Subjective } \\
\text { discount }\end{array}$ & -0.003 & 0.013 & -0.018 & 0.003 \\
Observations & $(0.640)$ & $(0.480)$ & $(0.106)$ & $(0.813)$ \\
\hline
\end{tabular}

This table shows marginal values of probit estimates of the effect of accessibility to pre-existing risks on the probability of rejection of the small lottery for individuals that differ in the reliance on intuition and reasoning when making decisions. The left hand side is a dummy equal to 1 if the small lottery has been turned down; it is equal to zero if either had been accepted or the individual has answered "I do not know". Accessibility is a variable equal to 1 if the lottery question was asked just after elicitation of the probability distribution of income one year-ahead and zero if asked at the beginning of the questionnaire. Coefficients are marginal effects of probit regressions. $p$ values are reported in parenthesis; *** significant at $1 \%$ or less, $* *$ significant at $5 \%, *$ significant at $10 \%$

educated and did somewhat worse in junior high school. Second, If we split the sample by level of education (below and above high school) and run the regression in Table 8 , the coefficient of accessibility is statistically significant in both groups; though very similar, it is if anything higher in the low education group ( -0.096 and -0.090 , respectively). A similar result obtains if we use the self-reported measure of relative performance in secondary school: dividing the sample between those who were above average or among the top students in secondary school and those who were average or below, accessibility has a slightly larger effect on the rejection rate in the low than in the high aptitude group ( -0.089 and -0.080 respectively) but effects are in both cases similar.

A still different objection to the thinking mode indicator is that it could be biased towards reporting reasoning as this may convey a better opinion of himself to the interviewer than answering that one decides on intuition. Even though it is unclear that reliance on intuition is considered to be socially bad (intuitive thinking can be viewed as an assets (Klein 2003), and is positively correlated with education), if some intuitive thinkers describe themselves as relying on reasoning, then the difference in accessibility across different thinking modes estimated in Table 8 is a lower bound of the true difference, which only reinforces our conclusion.

Table 9 expands the evidence with regressions of the rejection rate on income risk. If what shapes narrow framing is the extent to which individuals rely on reasoning or intuition, one should expect the effect of income risk to be strongest (that is most negative) among those who have been given access to it and who rely on reasoning, and to be weakest for those who base decisions on intuition even if they have been given access to their pre-existing risks. To test this, I run regressions splitting each thinking mode group between those with and without access to earnings risk. Distinguishing between high and low accessibility among intuitive thinkers I find that income uncertainty has no significant impact, not only for those who are not exposed to their income risk before deciding but also for those who are (columns 1 and 2). The same holds true for the group that typically combines intuition and reasoning (columns 3 and 4). However, for the third group I find that income risk when they are given access to it 
Table 9 Income risk, accessibility and the role of intuitive thinking and reasoning

\begin{tabular}{|c|c|c|c|c|c|c|}
\hline & (1) & (2) & (3) & (4) & (5) & (6) \\
\hline & \multicolumn{2}{|c|}{ Rely on intuition } & \multicolumn{2}{|c|}{ Intuition and reasoning } & \multicolumn{2}{|c|}{ Rely on reasoning } \\
\hline & $\begin{array}{l}\text { High } \\
\text { accessibility }\end{array}$ & $\begin{array}{l}\text { Low } \\
\text { accessibility }\end{array}$ & $\begin{array}{l}\text { High } \\
\text { accessibility }\end{array}$ & $\begin{array}{l}\text { Low } \\
\text { accessibility }\end{array}$ & $\begin{array}{l}\text { High } \\
\text { accessibility }\end{array}$ & $\begin{array}{l}\text { Low } \\
\text { accessibility }\end{array}$ \\
\hline \multirow[t]{2}{*}{ Uncertainty } & -0.004 & -0.115 & 0.054 & -0.100 & $-0.210 * * *$ & 0.013 \\
\hline & $(0.943)$ & $(0.327)$ & $(0.372)$ & $(0.114)$ & $(0.001)$ & $(0.841)$ \\
\hline \multirow[t]{2}{*}{ Regret losses } & -0.043 & -0.020 & 0.060 & $0.081 *$ & $0.087 * *$ & 0.053 \\
\hline & $(0.197)$ & $(0.795)$ & $(0.148)$ & $(0.068)$ & $(0.027)$ & $(0.145)$ \\
\hline \multirow{2}{*}{$\begin{array}{l}\text { Regret missed } \\
\text { gains }\end{array}$} & 0.010 & -0.133 & $-0.108 * *$ & $-0.105^{*}$ & $-0.135 * * *$ & $-0.082 *$ \\
\hline & $(0.793)$ & $(0.173)$ & $(0.024)$ & $(0.055)$ & $(0.002)$ & $(0.052)$ \\
\hline \multirow[t]{2}{*}{ Age } & -0.000 & -0.001 & $0.005 * *$ & -0.001 & 0.000 & 0.001 \\
\hline & $(0.957)$ & $(0.854)$ & $(0.042)$ & $(0.724)$ & $(0.904)$ & $(0.600)$ \\
\hline \multirow[t]{2}{*}{ Male } & 0.074 & -0.043 & 0.033 & -0.061 & -0.015 & -0.040 \\
\hline & $(0.200)$ & $(0.716)$ & $(0.580)$ & $(0.331)$ & $(0.820)$ & $(0.511)$ \\
\hline \multirow[t]{2}{*}{ Education } & -0.008 & 0.002 & -0.004 & $-0.014^{* *}$ & $0.013 * *$ & 0.002 \\
\hline & $(0.178)$ & $(0.872)$ & $(0.617)$ & $(0.048)$ & $(0.048)$ & $(0.787)$ \\
\hline \multirow[t]{2}{*}{ Married } & 0.045 & 0.103 & $0.110^{*}$ & 0.092 & 0.044 & -0.030 \\
\hline & $(0.387)$ & $(0.374)$ & $(0.054)$ & $(0.131)$ & $(0.481)$ & $(0.622)$ \\
\hline \multirow[t]{2}{*}{ North } & -0.023 & -0.086 & $-0.130^{*}$ & 0.009 & -0.024 & 0.049 \\
\hline & $(0.702)$ & $(0.528)$ & $(0.060)$ & $(0.905)$ & $(0.711)$ & $(0.451)$ \\
\hline \multirow[t]{2}{*}{ Centre } & 0.018 & -0.094 & $-0.158 * *$ & 0.096 & -0.110 & -0.031 \\
\hline & $(0.801)$ & $(0.544)$ & $(0.043)$ & $(0.218)$ & $(0.152)$ & $(0.671)$ \\
\hline \multirow[t]{2}{*}{ City size } & $-0.043^{*}$ & -0.077 & -0.034 & $-0.044^{*}$ & $-0.070 * * *$ & $-0.042^{* *}$ \\
\hline & $(0.087)$ & $(0.122)$ & $(0.150)$ & $(0.067)$ & $(0.004)$ & $(0.049)$ \\
\hline \multirow{2}{*}{$\begin{array}{l}\text { Financial } \\
\text { wealth }\end{array}$} & -0.360 & -0.396 & -0.045 & $0.405^{* *}$ & -0.170 & -0.039 \\
\hline & $(0.248)$ & $(0.243)$ & $(0.775)$ & $(0.034)$ & $(0.412)$ & $(0.906)$ \\
\hline \multirow{2}{*}{$\begin{array}{r}\text { (Financial } \\
\text { wealth }^{2}\end{array}$} & 0.472 & 0.071 & 0.010 & $-0.113 * *$ & 0.100 & -0.056 \\
\hline & $(0.179)$ & $(0.604)$ & $(0.710)$ & $(0.043)$ & $(0.292)$ & $(0.843)$ \\
\hline \multirow[t]{2}{*}{ Income } & -0.546 & -0.604 & -1.559 & 1.259 & -0.862 & 1.546 \\
\hline & $(0.477)$ & $(0.749)$ & $(0.140)$ & $(0.126)$ & $(0.492)$ & $(0.190)$ \\
\hline \multirow[t]{2}{*}{$(\text { Income })^{2}$} & 0.005 & -0.616 & 2.263 & -2.255 & 3.516 & -4.429 \\
\hline & $(0.998)$ & $(0.906)$ & $(0.308)$ & $(0.119)$ & $(0.352)$ & $(0.220)$ \\
\hline \multirow{2}{*}{$\begin{array}{l}\text { Medium risk } \\
\text { aversion }\end{array}$} & -0.068 & -0.096 & 0.099 & 0.092 & 0.023 & -0.028 \\
\hline & $(0.186)$ & $(0.391)$ & $(0.105)$ & $(0.150)$ & $(0.719)$ & $(0.669)$ \\
\hline \multirow{2}{*}{$\begin{array}{l}\text { High risk } \\
\text { aversion }\end{array}$} & -0.117 & 0.152 & 0.119 & $0.259 * * *$ & $0.133^{*}$ & 0.091 \\
\hline & $(0.155)$ & $(0.303)$ & $(0.172)$ & $(0.002)$ & $(0.096)$ & $(0.262)$ \\
\hline \multirow{2}{*}{$\begin{array}{l}\text { Generalized } \\
\text { trust }\end{array}$} & $-0.089 *$ & -0.141 & -0.039 & $-0.221 * * *$ & -0.109 & 0.016 \\
\hline & $(0.097)$ & $(0.233)$ & $(0.506)$ & $(0.000)$ & $(0.142)$ & $(0.791)$ \\
\hline
\end{tabular}

reduces the rejection rate by as much as $21 \%$ points (column 5), 1/3 of its unconditional mean, and the effect is highly statistically significant ( pvalue $=0.001$ ). On the other hand, income risk has no effect on those with low accessibility, even if they base 
Table 9 continued

\begin{tabular}{|c|c|c|c|c|c|c|}
\hline & (1) & (2) & (3) & (4) & (5) & (6) \\
\hline & \multicolumn{2}{|c|}{ Rely on intuition } & \multicolumn{2}{|c|}{ Intuition and reasoning } & \multicolumn{2}{|c|}{ Rely on reasoning } \\
\hline & $\begin{array}{l}\text { High } \\
\text { accessibility }\end{array}$ & $\begin{array}{l}\text { Low } \\
\text { accessibility }\end{array}$ & $\begin{array}{l}\text { High } \\
\text { accessibility }\end{array}$ & $\begin{array}{l}\text { Low } \\
\text { accessibility }\end{array}$ & $\begin{array}{l}\text { High } \\
\text { accessibility }\end{array}$ & $\begin{array}{l}\text { Low } \\
\text { accessibility }\end{array}$ \\
\hline Subjective discount & $\begin{array}{l}0.008 \\
(0.525)\end{array}$ & $\begin{array}{l}-0.003 \\
(0.910)\end{array}$ & $\begin{array}{l}-0.009 \\
(0.579)\end{array}$ & $\begin{array}{l}-0.035^{* *} \\
(0.032)\end{array}$ & $\begin{array}{l}0.014 \\
(0.355)\end{array}$ & $\begin{array}{l}-0.009 \\
(0.552)\end{array}$ \\
\hline Observations & 119 & 126 & 382 & 338 & 384 & 334 \\
\hline
\end{tabular}

This table shows marginal values of probit estimates of the effect of pre-existing risks on the probability of rejection of the small lottery for individuals that differ both in accessibility to pre-existing risks and in the reliance on intuition and reasoning when making decisions. The left hand side is a dummy equal to 1 if the small lottery has been turned down; it is equal to zero if either had been accepted or the individual has answered "I do not know". Income uncertainty is a dummy equal to 1 if the expected maximum income one year ahead exceeds the minimum and zero if the two coincide. High accessibility refers to individuals that have answered the small lottery question after elicitation of the probability distribution of income one year-ahead; low accessibility if answered at the beginning of the questionnaire. Coefficients are marginal effects of probit regressions. $p$ values are reported in parenthesis; $* * *$ significant at $1 \%$ or less, $* *$ significant at $5 \%$, * significant at $10 \%$

their decision on reasoning (column 6). ${ }^{16}$ This suggests that unless the pre-existing risk is evoked when a decision is made, it may be overlooked even by people who decide on the basis of effortful reasoning; that is, reasoning alone may not be sufficient to overcome narrow framing.

\section{Bounding the Degree of Narrow Framing}

In this section I provide estimates of the sample distribution of the maximum and minimum value of the degree of narrow framing for the individuals in our sample. For this I rely on a simplified version of the model discussed in Sect. 2. Namely, suppose that when assessing the lottery individuals ignore the effect that accepting may have on their current consumption and assess only its ability to provide insurance against their earnings risk. As Barberis and Huang (2006) show this simplification is unlikely to make a difference. Thus, I assume individual $i$ utility is

$$
V_{i t}=\left(1-b_{i}\right) E U\left(\tilde{y}_{i, t+1}+\tilde{x}_{t+1}\right)+b_{i} E v\left(\widetilde{x}_{t+1}\right)
$$

where $\tilde{y}_{i t+1}$ is his future earnings and the lottery has no subscript, being the same for all individuals. The first term is the expected utility when the individual merges the

16 It can be objected that Intuitive thinkers may be give more approximate answers than those who rely on reasoning when reporting the distribution of future earnings and may fail to report uncertainty even when, reasoning on it, they actually face some. This may explain why uncertainty matters more for those who rely on reasoning. However, this does not seem to be the case. The fraction of those facing uncertainty in the whole sample is $38 \%$ among those who rely mostly on intuition and $39 \%$ among those who mosty rely on reasoning. Excluding the retired these proportions are 63 and $68 \%$ respectively. I addition the correlation between the range of the distribution among those facing some risk and thinking mode shows that those who rely on reasoning report lower average uncertainty. 
lottery with his future earnings while the second captures the direct utility when he frames lottery narrowly. The degree of narrow framing is $b_{i}$ and is individual specific. its value is comprised between 0 and 1 (as in Rabin and Weizsacker 2009) with a value of zero denoting absence of narrow framing and 1 full narrow framing. An individual turns down the lottery if:

$$
\left(1-b_{i}\right) E U\left(\widetilde{y}_{i, t+1}+\widetilde{x}_{t+1}\right)+b_{i} E v\left(\widetilde{x}_{t+1}\right)>\left(1-b_{i}\right) E U\left(\widetilde{y}_{i, t+1}\right)
$$

Let $\bar{b}_{i}$ be the threshold value of narrow framing that makes a person indifferent between accepting and turning the lottery down, defined as:

$$
\bar{b}_{i}=\frac{\Delta}{\Delta-E v\left(\widetilde{x}_{t+1}\right)}
$$

where $\Delta=E U\left(\widetilde{y}_{i, t+1}+\widetilde{x}_{t+1}\right)-E U\left(\widetilde{y}_{i, t+1}\right)$ is the utility gain from accepting the lottery in the absence of narrow framing. Thus an individual with $b_{i}>\bar{b}_{i}$ will turn the lottery down while an individual with $b_{i}<\bar{b}_{i}$ will accept it. We will use the information on the probability distribution of individual earnings to compute for each individual in our sample the threshold $\bar{b}_{i}$. Since we observe the actual decision about the lottery we can then infer whether his actual $b_{i}$ exceed the threshold (if he has turned down the lottery) or is below the threshold (if he has accepted it). Letting $v($ ) be piecewise linear and characterized by loss aversion, $E v\left(\widetilde{x}_{t+1}\right)=180-\lambda 100=$ -10 under the assumption that the loss aversion parameter is $\lambda=2$ (as we assume in our main calculations). The value of $\Delta$ depends on the nature of the utility function $U$ ( ). I assume that also $U$ is characterized by loss aversion. In particular I assume that $U()$ is piecewise linear around a reference point given by the mid-point of the distribution of future earnings and that the loss aversion parameter is $\lambda=2$. As shown by Barberis et al. (2006) provided $\tilde{y}_{i, t+1}$ exhibits some uncertainty, $\Delta$ will always be positive. Since $\bar{b}_{i}$ is only defined for the individuals who actually face some earnings risk, calculations are made for those with a positive range of future earnings, under the assumption that $\widetilde{y}_{i, t+1}$ is distributed uniformly below and above the midpoint of its range, and assuming a degree of loss aversion equal to 2 .

In Table 10 I report various moments of the sample distribution of $\Delta$ for the whole sample (first column) and of $\bar{b}_{i}$, both for the whole sample and for the sample of those who reject and accept the lottery. As can be seen the value of $\Delta$ is positive at all moments, implying that in the absence of narrow framing all should accept the lottery even under loss-averse preferences. In the whole sample, the median value of $\bar{b}_{i}$ is 0.85 and the overall distribution is relatively concentrated, as implied by the small value of the standard deviation (0.023) and the contained difference between the 1th and 99th percentile (second column). The third and fourth column show the distribution of $\bar{b}_{i}$ for those who have rejected and accepted the lottery, respectively. As can be seen the two distributions are very similar. These estimates suggest a substantial degree of narrow framing. We can infer that for 99 percent of those who have turned down the lottery the actual degree of narrow framing exceeds 0.78 while for those who have accepted it only for 1 percent of them it must be below 0.78 . These estimates are reminiscent of those of Rabin and Weizsacker (2009) who use as a measure of the degree of narrow 
Table 10 Distribution of the minimum and maximum degree of narrow framing

\begin{tabular}{lclll}
\hline & $\begin{array}{l}\text { Value of } \Delta: \\
\text { total sample }\end{array}$ & $\begin{array}{l}\text { Threshold of } \\
\text { narrow framing: } \\
\text { Total sample }\end{array}$ & $\begin{array}{l}\text { Threshold of narrow } \\
\text { framing: sample of } \\
\text { those who turn the } \\
\text { lottery down }\end{array}$ & $\begin{array}{l}\text { Threshold of narrow } \\
\text { framing: sample of } \\
\text { those who accept } \\
\text { the lottery }\end{array}$ \\
\hline 1 th $\% 0$ & 33.5 & 0.778 & 0.778 & 0.778 \\
5 th $\% 0$ & 39.7 & 0.799 & 0.798 & 0.800 \\
10 th $\% 0$ & 43.9 & 0.820 & 0.816 & 0.820 \\
25 th $\% 0$ & 51.3 & 0.841 & 0.841 & 0.842 \\
50 th $\% 00$ & 59.9 & 0.854 & 0.854 & 0.855 \\
75 th $\% 00$ & 70.6 & 0.867 & 0.867 & 0.867 \\
90th $\% 0$ & 81.8 & 0.877 & 0.878 & 0.877 \\
95th $\% 0$ & 86.1 & 0.882 & 0.882 & 0.880 \\
99th $\% 0$ & 102.9 & 0.885 & 0.987 & 0.883 \\
Mean & 61.6 & 0.850 & 0.850 & 0.851 \\
Standard deviation & 14.8 & 0.024 & 0.025 & 0.023 \\
Observations & 6.55 & 655 & 368 & 287 \\
\hline
\end{tabular}

This table shows estimates of distribution of the minimum degree of narrow framing among those who turn down the lottery and the maximum degree of narrow framing among those who have accepted it. Estimates have been conducted assuming that individuals have loss-averse preferences with a degree of loss aversion equal to 2 and that the reference point is the midpoint of the range of the distribution of the individual future earnings

framing the fraction of individuals who are exposed to the risk of choosing dominated prospects and estimate this fraction at around 0.9, signalling a high degree of narrow framing.

The estimate of the distribution of $\bar{b}_{i}$ is only marginally affected if we allow for a higher degree of loss aversion or for heterogeneity in the loss aversion parameter or if we assume that $\tilde{y}_{i, t+1}$ follows a triangular distribution below and above the midpoint of its range. ${ }^{17}$

\section{Conclusions}

I have designed a new test of models that rely on narrow framing to explain why individuals, even at high levels of wealth, turn down small advantageous lotteries that would be appealing in a framework of maximization of expected utility of final wealth. The evidence is consistent with the hypothesis that people focus on the most visible properties of the lottery and tend to ignore its interaction with other wealth

\footnotetext{
17 If I assume a uniform degree of loss aversion equal to 3 the median value of $\bar{b}_{i}$ is 0.88 (sd 0.036 ), the 1 th percentile is 0.78 and the 99 th percentile 0.92 . To allow for different degrees of loss aversion I have assumed that those who dislike risk more are also more averse to losses and imputed values of loss aversion of $1.2,1.65,2.30$ and 3 respectively to the four groups of risk aversion in the sample using the qualitative indicator of risk aversion. In this case the median value of $\bar{b}_{i}$ is 0.85 ( $\left.\mathrm{sd} 0.031\right)$, the 1 th percentile is 0.77 and the 99th percentile 0.91 .
} 
components. When encouraged to first evoke pre-existing risks and only afterwards asked to decide on participation in the lottery, individuals are found to be significantly less likely to reject it, as if they become aware of its diversification benefits when the other risks they can hedge are made readily perceptible. This is particularly true for individuals that actually face income risk, precisely those who can effectively benefit from the potential diversification.

A second contribution of this paper is that it is the first, as far as I know, to provide evidence on the origins of narrow framing. I show that regret over losses and gains strongly affects the decision to accept or reject the offered lottery, while mode in which individuals make decisions seems critical in explaining the degree of narrow framing. Consistent with narrow framing theories, I find that people who benefit the most from exposure to pre-existing risks are those who base decisions on reasoning; those who decide on intuition are unresponsive to accessibility to pre-existing risks and appear to weigh only the specific properties of the lottery.

While this evidence suggests that narrow framing may be a relevant property of individual preferences, one needs to be aware of the setting in which this evidence was obtained. It may be legitimately objected that a hypothetical lottery is not the best way to assess individuals' dependence on narrow framing and that when faced with real-life decisions-like their stock portfolio allocation - people have powerful incentives to depart from the specific features of the assets they could buy and to consider how they relate to the various components of their (uncertain) wealth. To account for this problem at least in part we have been careful in framing the lottery as a small investment; but of course the proper wording may not be enough. The only way to overcome this potentially valid objection is to design a field experiment where, for instance, one studies individual willingness to invest in stocks by comparing the choices of a treatment group to whom a broker has evoked their pre-existing risks with that of a control group. This is the next step in my research agenda.

\section{Data Appendix}

\subsection{The UCS Survey}

The data used in this paper draw on a sample of Italian clients of the Unicredit Group. The Unicredit Clients' Survey (UCS) was conducted between June and September 2007 and elicits detailed financial and demographic information on a sample of 1,686 individuals with a checking account in one of the banks of the UniCredit Group. The sample is stratified according to three criteria: geographical area, city size, financial wealth, and it is explicitly over-samples rich clients. In particular, only clients with at least 10,000 euros of financial wealth at Unicredit at the end of 2006. The survey is CAPI.

An important feature of the survey is that the sample selection is based on individual clients of Unicredit. The survey, however, contains detailed information on the spouse, if present. Financial variables are elicited for both respondents and households. In the paper, demographic variables refer to the household head (even if different from the respondent), and economic variables (real and financial assets) to the household, not 
to the individual investor. The survey contains detailed information on ownership of real and financial assets, and amount invested. For real assets, UCS reports separate data on primary residence, investment real estate, land, business wealth, and debt (distinguished between mortgage and other debt). Real asset amounts are elicited without use of bracketing.

\subsection{Definition of Variables Constructed from Survey Responses}

Income. Value of the personal income of the survey respondent (thousand of euros). This figures is obtained from then answers to the survey.

Financial wealth. Value of financial assets of the respondent (thousands of euros). Obtained from the administrative records of Unicredit. For privacy reasons the value of financial has been recomputed by first sorting assets increasing order and then replacing the value of the assets of individual $j$ with a three-term average computed using individual $j$ 's assets and the two adiacent observations. The correlation between the true and imputed value if 0.99 .

Income risk. Based on question about the probability distribution of one-year ahead earnings as reported in the text. This question is answered by all active workers. For non-active, retired workers we set earnings uncertainty equal to zero. We code it equal to 1 if the range of the probability distribution is positive and zero otherwise.

Education. Number of years of schooling, including primary, secondary, college and post-college education.

Cognitive ability. Obtained from the following questions: "Think of when you attended secondary school. How did you compare relatively to your class mates? (1) Among the top 5; (2) well above average; (3) about average; (4) somewhat below average." The variable is coded between 1 and 4, with larger values denoting higher ability.

Demographics. Demographics such as age, gender,marital status, geographic location, city size are obtained from answers to the questionnaire.

Risk aversion. we use two indicators. The first is based on the question: "Which of the following statements comes closest to the amount of financial risk that you are willing to take when you make your financial investment?: (1) a very high return, with a very high risk of loosing the money; (2) high return and high risk; (3) moderate return and moderate risk; (4) low return and no risk." As an alternative indicator we use: "With which of the following statements do you agree most? (1) Risk is an uncertain event from which one can extract a profit; (2) Risk is an uncertain event from which one should seek protection." We define four dummy variables one for each level of risk aversion. The second indicator relies on the following question: "Think of being in a room and to get out you can choose between two doors: if you choose the right door you win a 10,000 euros prize; if you choose the wrong door you win nothing. You have also the give up the possibility of choosing between one of the two doors and exit from a back door, in which case you get a known certain amount of money. 
If I offer you $X$ euros would you give up the possibility of choosing between the two doors and leave from the back door?"

$X$ takes values of increasing amounts starting from 100 euros to 9,000 euros. If the 100 euros for sure are preferred to the choice of one of the two doors, the process stops. Otherwise another larger value of $X$ is offered until the safe bet is chosen. This value is then used to identify the degree of risk aversion. The indicator is coded as the first sure value at which the person switches. Clearly, larger values denote lower risk aversion

Generalized trust. Response to question: "Generally speaking, would you say that most people can be trusted or that you can't be too careful in dealing with people?". Coded a" 0 = can't be too careful; 1 : most people can be trusted.

Interview length. Minutes the interview lasted. This information is automatically recorded by the computer.

Interview climate, understanding and easiness in answering. Qualitative indicators reported at the end of the interview by the interviewers. The judgement is on scale between 1 and 10, with 1 standing for poor climate (understanding, easiness in answering questions) and 10 excellent climate (understanding, easiness in answering questions).

\section{References}

Antonio D (1994) Descartes' error: emotion, reason and the human brain. G.P. Putnam' Sons, New York Barberis N, Huang M, Santos T (2001) Prospect theory and asset prices. Q J Econ 2001 116(1):1-53

Barberis N, Huang M (2006) The loss aversion/narrow framing approach to the equity premium puzzle. In: Mehra R (ed) Handbook of investments: equity premium. Elsevier Science, Amsterdam

Barberis N, Huang M, Richard T (2006) Individual preferences, monetary gambles and stock market participation. Am Econ Rev 96(4):1069-1090

Barsky RB, Juster T, Kimball MS, Shapiro MD (1997) Preference parameters and behavioral heterogeneity: an experimental approach in the health and retirement survey. Quart J Econ 112:537-580

Benjamin D, Brown SM, Shapiro J (2006) Who is Behavioral? Cognitive ability and anomalous preferences. University of Chicago, Mimeo

Bouchard Jr. TJ, Hur Y (1998) Genetic and environmental influences on the continuous scales of the Myers-Briggs Type Indicator: an analysis based on twins reared apart. J Pers 6(2):136-149

Breiter HC, Aharon I, Kahneman D, Dale A, Shizgal P (2001) Functional imaging of neural responses to expectancy and experience of monetary gains and losses. Neuron 30:619-639

Brocas I, Carrillo JD (2008a) Theories of the mind. Am Econ Rev Papers Proc 98(2):175-180

Brocas I, Carrillo JD (2008b) The brain as a hierarchical organization. Am Econ Rev 98(4):1312-1346

Brown JR, Kling JR, Mullainathan S, Wrobel MV (2008) Why don't the people insure late life consumption? A framing explanation of the under-annuitization puzzle. Am Econ Rev P\&P 98(2):304-309

Butler J, Guiso L, Jappelli T (2013) Manipulation of reliance on intuition reduces risk and ambiguity aversion CEPR DP 9461

Butler J, Guiso L, Jappelli T (2014) The role of intuition and reasoning in driving aversion to risk and ambiguity. Theory and decision (Forthcoming)

Camerer C, Babcock L (1995) Labor supply of New York city cab drivers: one day at a time. Q J Econ 112:407-441

Chetty R, Szeidl A (2007) Consumption commitments and risk preferences. Q J Econ 2007 122(2):831-887

Choi J, Laibson D, Madrian BC (2009) Mental accounting in Portfolio choice: evidence from a flypaper effect. Am Econ Rev 99(5):2085-2095 
Damasio AR, Tranel D, Damasio H (1990) Individuals with sociopathic behavior caused by frontal damage fail to respond autonomically to social stimuli. Behav Brain Res, 41(2):81-166, pp 81-94

Dohmen TJ, Falk A, Huffman D, Sunde U (2008) Are risk aversion and impatience related to cognituve ability? CEPR DP, No 6852

Dohmen T, Falk A, Huffman D, Sunde U, Schupp J, Wagner GG (2011) Individual risk attitudes: measurement, determinants and behavioral conseqeunces. J Eur Econ Assoc 9(3):522-550

Evans JSBT, Over DE, Manktelow K (1993) Reasoning, decision making and rationality. Cognition 49:165187

Frederick S (2005) Cognitive reflection and decision-making. J Econ Persp 19(4):24-42

Fudenberg D, Levine DK (2006) A dual self model of impulse control. Am Econ Rev 96(5):1449-1476

Guiso L, Pistaferri L (2002) An empirical analysis of earnings and employment risk. J Bus Econ Stat 20(2):241-253

Guiso L, Paiella M (2008) Risk aversion, wealth and background risk. J Eur Econ Assoc 6(6):1109-1150

Guiso L, Sapienza P Zingales L (2008) Trusting the stock market. J Financ, 6(63):2557-2600

Gul F (1991) A theory of disappointment aversion. Econometrica 59(3):667-686

Haliassos M, Bertaut CC (1995) Why do so few hold stocks? Econ J 105(432):1110-1129

Hammond KR (1996) Human judgment and social policy. Oxford University Press, Oxford

Higgins ET (1996) Knowledge activation: accessibility, applicability, and salience. In: Higgins ET, Kruglanski AW (eds), Social psychology: handbook of basic principles. Guilford Press, New York, pp 133-68

Kahneman D (2011) Thinking fast and slow. MacMillan NY

Kahneman D, Tversky A (1982) The psychology of preferences. Sci Am 246(1):160-173

Kahneman D, Lovallo D (1993) Timid choices and bold forecasts: a cognitive perspective on risk taking. Manage Sci 39(1):17-31

Kahneman D (2003) Maps of bounded rationality: psychology for behavioral economics. Am Econ Rev 93(5):1449-1475

Kirby KN, Winston GC, Sentiesteban M (2005) Impatience and grades: delay-discount rates correlate negatively with college GPA. Learn Individ Differ 15(3):213-222

Klein G (2003) Intuition at work: why developing your gut instincts will make you better at what you do. Doubleday, New York

Kumar A, Lim SS (2008) How do decision frames influence the stock investment choices of individual investors? Manage Sci 54(6):1052-1064

Mankiw NG, Zeldes SP (1991) The consumption of stockholders and nonstockholders. J Financ Econ 29(1):97-112

McClure SM, Laibson DI, Loewenstein G, Cohen JD (2004) Separate neural systems value immediate and delayed monetary rewards. Sci Oct 306:503-507

Rabin M (2000) Risk aversion and expected-utility theory: a calibration theorem. Econometrica 68(5):12811292

Rabin M, Thaler R (2001) Anomalies: risk aversion. J Econ Persp 15(1):219-232

Rabin M, Weizsacker G (2009) Narrow bracketing and dominated choices. Am Econ Rev 99(4):1508-1543

Read D, Loewenstein G (1995) Diversification bias: explaining the discrepancy in variety seeking between combined and separated choices. J Exp Psychol Appl 1:34-49

Read D, Loewenstein G, Rabin M (1999) Choice bracketing. J Risk Uncertain 1(1-3):171-197

Redelmeier DA, Tversky A (1992) On the framing of multiple prospects. Psychol Sci 3(3):191-193

Roese NJ, Olson JM (eds) (1995) What might have been: the social psychology of counterfactual thinking. Erlbaum, Mahwah

Sabini J, Silver M (1982) Moralities of everyday life. Oxford University Press, Oxford

Sirigu A, Coricelli G, Sallet J, Camille N, Duhamel JR (2004) The involvement of the orbitofrontal cortex in the experience of regret, Science 304

Sloman SA (1996) The empirical case for two systems of reasoning. Psychol Bull 119:3-22

Stanovich KE, Richard FW (2002) Individual differences in reasoning: implications for the rationality debate? In: Thomas G, Dale G, Kahneman D (eds), Heuristics and biases: the psychology of intuitive thought. Cambridge University Press, New York, pp 421-40

Stanovich KE, West RF (2000) Individual differences in reasoning: implications for the rationality debate? Behav Brain Sci 23(5):645-665

Thaler RH, Tversky A, Kahneman D, Schwartz A (1997) The effect of myopia and loss aversion on risk taking: an experimental test. Quart J Econ 112(2):647-661 
Thaler R (2000) Mental accounting matters. In: Kahneman D, Tversky A (eds) Choices, values and frames. Cambridge University Press, Cambridge

Tversky A, Kahneman D (1981) The framing of decisions and the psychology of choice. Science 211(4481):453-458

Tversky A, Kahneman D (1991) Loss aversion in riskless choice: a reference dependent model. Quart J Econ 107(4):1039-1061

Tversky A, Kahneman D (1992) Advances in prospect theory: cumulative representation of uncertainty. J Risk Uncertain 5(4):297-323 